\title{
Could Vitamins Help in the Fight Against COVID-19?
}

\author{
Thomas H Jovic ${ }^{1,2, *}$, Stephen R Ali ${ }^{1,2, *}$, Nader Ibrahim ${ }^{1,2}$, Zita M Jessop ${ }^{1,2}$, Sam P Tarassoli ${ }^{1} \mathbb{D}$, \\ Thomas D Dobbs ${ }^{1,2}$, Patrick Holford ${ }^{3}$, Catherine A Thornton ${ }^{4}$ and Iain S Whitaker ${ }^{1,2, *, \dagger}$ \\ 1 Reconstructive Surgery \& Regenerative Medicine Research Group, Institute of Life Sciences, \\ Swansea University Medical School, Swansea University, Swansea SA28PY, UK; \\ Nader.Ibrahim@wales.nhs.uk (N.I.); Zita.Jessop@wales.nhs.uk (Z.M.J.); sam.tarassoli@wales.nhs.uk (S.P.T.); \\ Thomas.Dobbs@wales.nhs.uk (T.D.D.) \\ 2 Welsh Centre for Burns \& Plastic Surgery, Morriston Hospital, Swansea SA66NL, UK \\ 3 Institute for Optimum Nutrition, Ambassador House, Paradise Road, Richmond TW9 1SQ, UK; \\ pat@patrickholford.com \\ 4 Institute of Life Sciences 1, Swansea University Medical School, Swansea University, Swansea SA2 8PY, UK; \\ c.a.thornton@swansea.ac.uk \\ * Correspondence: Thomas.Jovic@wales.nhs.uk (T.H.J.); Stephen.Ali@wales.nhs.uk (S.R.A.); \\ iainwhitaker@fastmail.fm (I.S.W.); Tel.: +44-(0)1792-205-678 (I.S.W.) \\ $\dagger$ Equal first authors.
}

Received: 3 August 2020; Accepted: 20 August 2020; Published: 23 August 2020

\begin{abstract}
There are limited proven therapeutic options for the prevention and treatment of COVID-19. The role of vitamin and mineral supplementation or "immunonutrition" has previously been explored in a number of clinical trials in intensive care settings, and there are several hypotheses to support their routine use. The aim of this narrative review was to investigate whether vitamin supplementation is beneficial in COVID-19. A systematic search strategy with a narrative literature summary was designed, using the Medline, EMBASE, Cochrane Trials Register, WHO International Clinical Trial Registry, and Nexis media databases. The immune-mediating, antioxidant and antimicrobial roles of vitamins A to E were explored and their potential role in the fight against COVID-19 was evaluated. The major topics extracted for narrative synthesis were physiological and immunological roles of each vitamin, their role in respiratory infections, acute respiratory distress syndrome (ARDS), and COVID-19. Vitamins A to E highlighted potentially beneficial roles in the fight against COVID-19 via antioxidant effects, immunomodulation, enhancing natural barriers, and local paracrine signaling. Level 1 and 2 evidence supports the use of thiamine, vitamin C, and vitamin D in COVID-like respiratory diseases, ARDS, and sepsis. Although there are currently no published clinical trials due to the novelty of SARS-CoV-2 infection, there is pathophysiologic rationale for exploring the use of vitamins in this global pandemic, supported by early anecdotal reports from international groups. The final outcomes of ongoing trials of vitamin supplementation are awaited with interest.
\end{abstract}

Keywords: COVID-19; SARS-CoV-2; vitamin; immunonutrition; supplementation

\section{Introduction}

December 2019 saw clusters of patients in the city of Wuhan, Hubei Provence, China presenting with a severe acute respiratory syndrome coronavirus (SARS-CoV)-like illness. The causative organism, now termed SARS-CoV-2 and its correspondent disease, COVID-19, has quickly spread from Asia via Europe to the rest of the world. Previous viral pandemics due to novel corona and influenza viruses, such as SARS-CoV, Middle Eastern respiratory syndrome coronavirus (MERS-CoV), and H1N1 influenza A have been a warning to global healthcare. However, none of these pathogens have had such a catastrophic impact worldwide as the novel coronavirus SARS-CoV-2, a positive-sense 
single-stranded enveloped RNA virus, which is the seventh coronavirus known to infect humans [1]. RNA viruses are known to possess very high mutation rates, which correlate with enhanced virulence and evolvability [2]. COVID-19 highlights the potency of this, with a case-fatality rate of $2.3 \%$ and over $5,000,000$ infections in 216 countries at the time of writing [3,4]. The pandemic is gathering speed across the world despite increasingly more drastic non-pharmacological interventions to limit its spread. The clinical spectrum of COVID-19 ranges from asymptomatic carriage, mild upper respiratory tract infection (URTI), severe viral pneumonia to acute respiratory distress syndrome (ARDS) and death [5]. Research has led to identification of the angiotensin-converting enzyme (ACE) 2 as the cell-entry receptor for SARS-CoV-2 [6]. Despite this discovery, a systematic study of virus dynamics and the host response is yet to be completed [7].

Although vaccine development is proceeding at an unprecedented pace, with reports of phase 1 trials already in progress [8], given the length of time required to develop, evaluate, produce, and disseminate it to 7.8 billion citizens worldwide, there is an urgent need for evidence-based treatment modalities for SARS-CoV-2.

At present, no effective antiviral therapy has been confirmed and symptomatic supportive intervention is still the main treatment. There has been a previous suggestion that there is a role for vitamin supplementation to attenuate the severity of the common cold, the development of ARDS, and augment the immune system via antioxidant properties. The role of vitamin and mineral supplementation or "immunonutrition" has previously been explored in a number of trials in intensive care settings.

This review aims to interrogate the current evidence base, and to present the potential immune-mediating, antioxidant, and antimicrobial roles of vitamins $\mathrm{A}$ to $\mathrm{E}$ in the context of respiratory disease, and to extrapolate this evidence to evaluate the potential roles in the fight against COVID-19.

\section{Methods}

A systematic search strategy was employed to identify clinical, animal, and in vitro studies that may elucidate mechanisms by which vitamins may play a role in the fight against COVID-19. The Medline (1946-present), EMBASE (1980-present), Cochrane Trials Register, Clinicaltrials.gov, and WHO International Clinical Trial Registry were all searched using the developed search strategy up to 11 May 2020, supplemented with a search of newspaper and internet article sources using the media database, Nexis.

In total, 5506 manuscripts were screened for relevance, of which 367 underwent full-text review, with 204 studies warranting discussion in this narrative review (Figure 1). Figure 2 summarizes the Nexis search data and highlights the increasing media interest in the role of vitamin supplementation in the coronavirus pandemic since December 2019.

\section{Inclusion and Exclusion Criteria}

Case reports, case cohorts, case-control, randomized controlled studies, and meta-analyses were considered for inclusion. Specifically, studies involving humans or animals (including ex vivo and in vitro models) with a clinical (any recognized diagnostic criteria) diagnosis of SARS-CoV, SARS-CoV-2 infection, MERS-CoV, or viral-induced ARDS receiving vitamin supplementation of any form were included. In addition to non-English language articles, lipopolysaccharide (LPS) animal models of ARDS and clinical studies where the etiology of ARDS included sepsis were avoided. This was because the clinical course of the viral pneumonia seen in COVID-19 has been described as an entity distinct from the Third International Consensus Definitions for Sepsis and Septic Shock. There was a paucity of published original evidence pertaining to a role of vitamin supplementation in the current coronavirus pandemic, or previous MERS and SARS pandemics. As such, studies on the role of vitamins in respiratory and immune system physiology and non-coronavirus respiratory tract infections were identified and scrutinized for their potential relevance to the current coronavirus pandemic. 


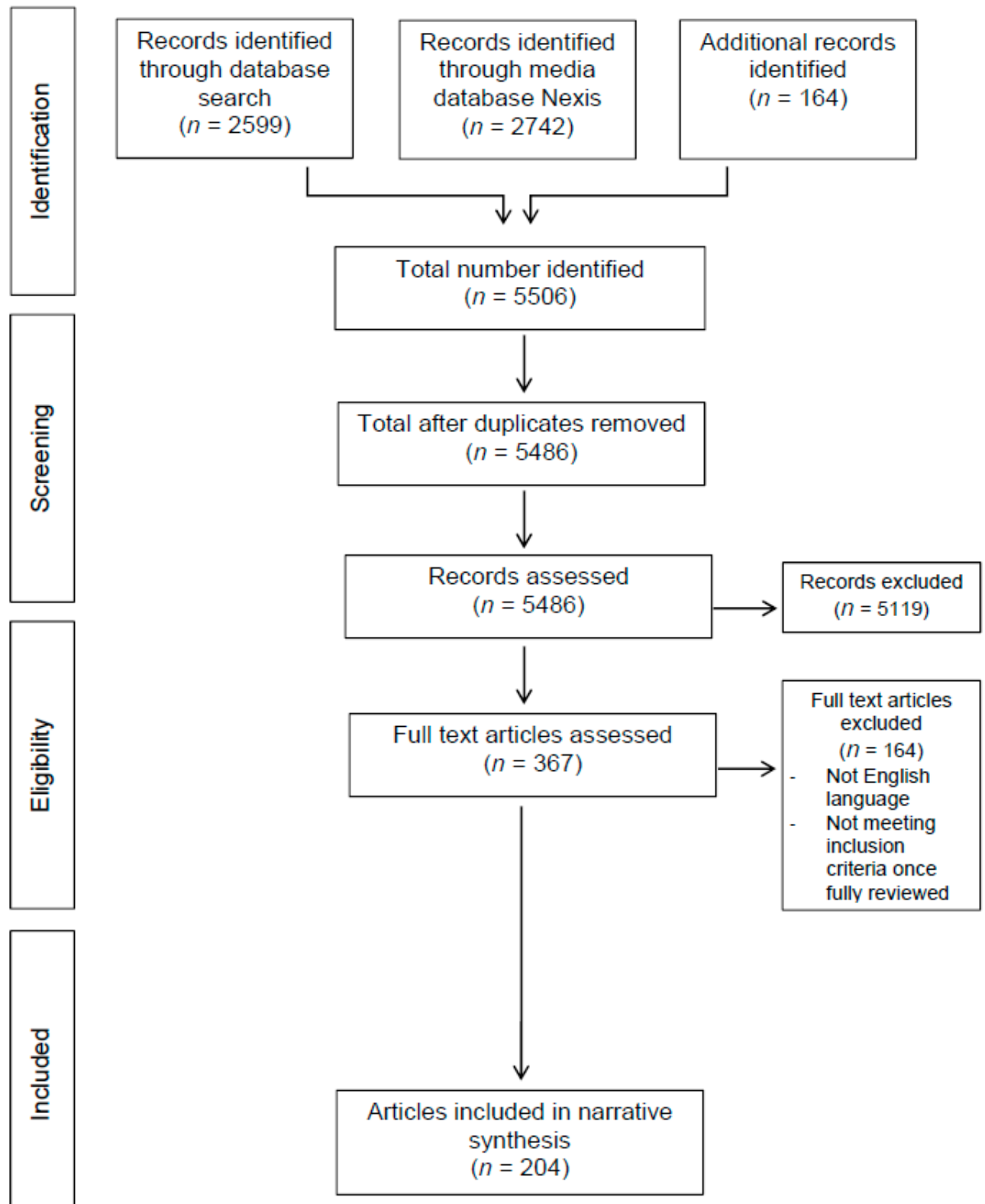

Figure 1. Systematic search strategy flow diagram. 


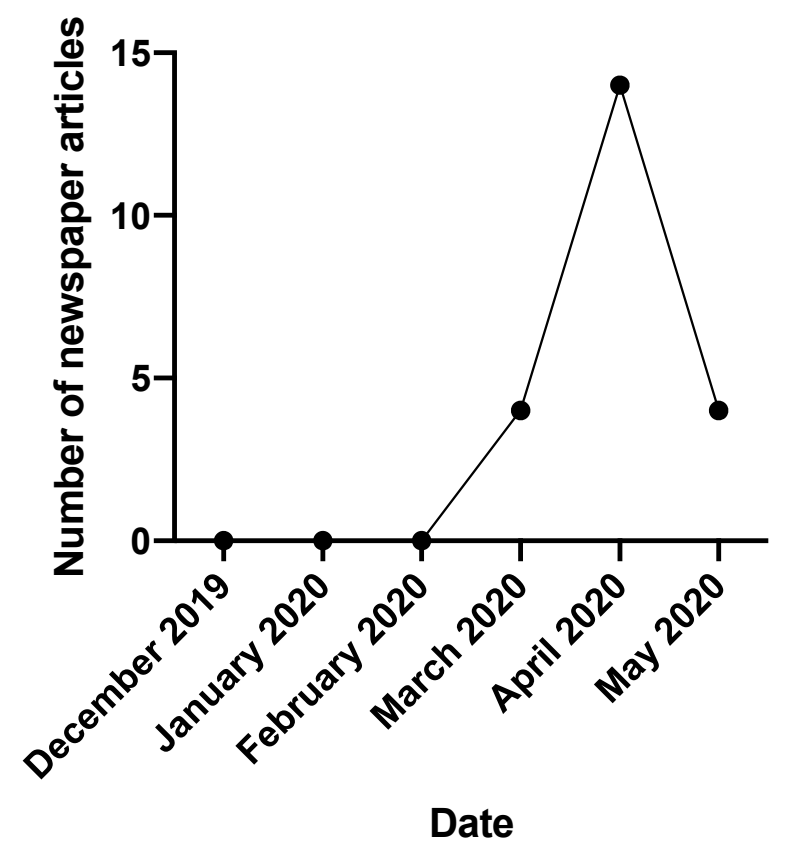

Figure 2. Number of newspaper articles published on vitamin supplementation in COVID-19 over time.

\section{Immunonutrition}

Immunonutrition refers to the modulation of the immune system through the modification of dietary nutrients [9]. Due to the proinflammatory state in ARDS it has been postulated for many years that increasing the level of antioxidant nutrients within the body will have a beneficial effect [10]. Furthermore, improving lymphocyte, macrophage, and neutrophil function through the addition of nutrients, such as glutamine, has also been described as being beneficial [11]. Dietary supplementation of nutrients has been recognized to alter the clinical course in a wide range of patients, including those who are critically ill [12]. There are a number of commercially available enteral and parenteral formulas containing a mix of immunonutrients. These most commonly consist of antioxidant vitamins, trace elements, essential amino acids, or fatty acids and gamma-linolenic acid [13].

The evidence supporting the beneficial effects of immunonutrition in acute lung injury (ALI) and ARDS is contradictory and often limited by significant bias. Clinical studies in patients with ARDS have shown that their baseline plasma levels of beta-carotene, retinol, alpha-tocopherol, and total radical antioxidant potential were all lower than normal. This could be normalized after 4 days of feeding with eicosapentaenoic acid, gamma-linolenic acid, and antioxidants, compared to a control group not receiving supplementation. There were, however, no clinical outcomes reported [14]. In a further randomized study investigating a similar supplementation of eicosapentaenoic acid, gamma-linolenic acid, and antioxidants (including vitamins) in patients with severe sepsis and septic shock, a significant reduction in 28-day mortality, ventilator-free days, and intensive care unit-free days was observed [15]. Despite these results, the systematic review and meta-analysis data of those reported studies is less promising. In a systematic review of enteral immunomodulatory diets in those with ALI and ARDS, it was found that in a pooled analysis of the six controlled trials included, there was no significant reduction in all-cause mortality and no increase in the number of ventilator-free or intensive care-free days [16]. There was a suggestion from the two studies that those at highest risk of mortality might, however, benefit. A 2019 Cochrane review identified 10 studies including 1015 ARDS patients randomized to dietary supplementation of omega-3 fatty acids and antioxidants. There was no reduction in all-cause mortality. There is a suggestion that ventilator-free days and intensive care unit-free days were reduced, although the authors conclude that this is uncertain due to the low quality of the evidence included [17]. 
The importance of immunonutrition during the current SARS-CoV-2 pandemic has been identified by others, with the publication of protocols for the early nutritional supplementation of those with the disease [18]. Reported work on this during this pandemic is limited. In many trials of dietary supplementation, the 'immunonutrition diet' is heterogenous, consisting of several vitamins, minerals, and fatty acids administered together, making it difficult to ascertain the potential value of each vitamin as discussed below.

\subsection{Vitamin A}

\subsubsection{Source and Physiological Role}

Vitamin A is, by structural definition, all-trans-retinol, a retinol in which all four exocyclic double bonds have an E- (also known as trans) geometry (Figure 3) [19-21]. Retinoids, a term coined in the mid-1970s, compromises both natural and synthetic chemical species that have similar structural appearances with or without biological component/activity, the biological species being those we colloquially refer to as vitamin A [22]. This would make vitamin A, a natural retinoid species. The acquisition of retinoids is generally from a dietary source in a preformed form or provitamin A carotenoids. The most active retinoid has been found to be retinoic acid. Retinoic acid has been discovered to regulate the transcription of more than 500 genes by its binding mechanism: RAR $\alpha / \beta / \gamma$ receptor to its retinoid $X$ counterpart [23].

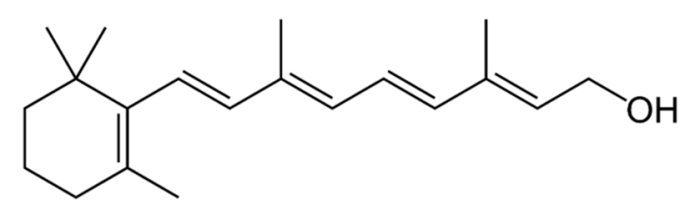

Figure 3. Chemical structure of vitamin A, retinol.

The sources of these are found commonly in animal food sources, such as meat, fish, and eggs. The carotenoids, generally in the form of alpha/beta/gamma carotene, are more likely to found in fruit and vegetables; $\beta$-carotene specifically contributes to the orange color of food and is typically associated with carrots and sweet potatoes [24]. These provitamin carotenoids are converted to retinoids in the body [25].

The site of action is throughout the tissues, where both retinol and $\beta$-carotene are oxidized to retinal and retinoic acid, which are essential for the variety of biological roles of vitamin A [26]. The liver plays a key role: Retinol is esterified to retinyl esters and stored in the stellate cells [27]. The oxidative ability of vitamin A has been the subject of much debate, with cases made for it being both antioxidative as well as pro-oxidative [28].

The biological functions of retinoids are wide and varied, including gene transcription [29], vision maintenance and health (in the form of retinal) [30], epithelial and membrane regulation (from skin to mucous to teeth) to bone metabolism, and antioxidative properties [31,32]. However, it has a major role in immune system modulation [19]. Although not fully understood, many studies provide evidence that vitamin A plays a crucial role in certain immunoregulatory processes. Vitamin A has been found to not only promote proliferation of T-lymphocytes (through the increase of IL-2) but to also promote their differentiation, especially into regulatory $\mathrm{T}$ cells. This has been interestingly used as an adjunct to vaccine use, including tetanus, diphtheria, measles, influenza, rabies, and malaria, in infants to improve the antibody response [33-36].

\subsubsection{Mechanism of Action in Disease}

Early work by Paiva et al. determined that vitamin A supplementation improved pulmonary function test results in patients with chronic obstructive pulmonary disease (COPD) [37]. This was explained on a cellular level by studies that showed that in fetal lung explants, retinoic acid (the most 
active retinoid species) was able to control the expression of surfactant protein [38-40]. Pediatric asthma studies (alongside supportive in vitro work) of vitamin A deficiency reinforced these theories by demonstrating that increased serum vitamin A induced good pulmonary function as retinoic acid can reverse airway hyper-responsiveness, in turn conferring protection from asthma by downregulation of oxidative stress $[38,40]$.

\subsubsection{Respiratory Infections}

Since 1928, vitamin A has been found to have antimicrobial qualities, tied to the immunemodulating factor of its derivatives [39,41]. Later studies showed that the risk of respiratory disease was 'more closely associated to vitamin A status then with general nutritional status [42]. The deficiency of retinol has also been discovered to cause squamous metaplasia of the first barrier of respiratory defense, the epithelium [43]. On a clinical basis, addressing vitamin A deficiency has effectively prevented tuberculosis (TB) in high-risk patients [44]. Though it should be noted that wide-scale studies have not shown a beneficial effect in areas of high prevalence of vitamin A deficiency [45]. Vitamin A is believed to have antioxidative properties, and has a key role in the development of bronchopulmonary dysplasia and neonatal respiratory distress syndrome [46,47]. This finding was pioneered by Hustead et al. in 1984 with his work on retinol concentrations in preterm infants, in which it was discovered that neonates developing bronchopulmonary dysplasia had lower concentrations of retinol at birth [48].

\subsubsection{Relevance to COVID-19}

The pulmonary, immunomodulatory, and antimicrobial roles of vitamin A may enact a crucial element in the fight against viral diseases, including COVID-19, and are summarized in Figure 4 [18]. From a pulmonary perspective, retinoic acid has been implicated in modulating the pathogenesis of ARDS, influencing the production of IL1- $\beta$ and IL-1 receptor antagonist by alveolar macrophages, and the subsequent pulmonary infiltration of neutrophils [49]. In addition, a study of retinoic acid with simvastatin has demonstrated augmented pulmonary regeneration and remodeling in animal studies [50], meaning both oxidative damage and the regenerative capacity of the lungs may be, in part, mediated through vitamin A-dependent mechanisms. There may also be relevance in the role of vitamin A in viral infections. Retinoids have been implicated in the development of an innate immunity against measles virus in vitro through an interferon-mediated mechanism, which in particular renders bystander cells protected against a subsequent round of viral replication [51]. The vitamin has been the subject of animal studies looking at inactivated bovine coronaviruses, with dietary supplements shown to increase the effect of antibody responses to the vaccine in feedlot calves [52], and lower levels of vitamin A in chickens with viral infections has been associated with an increased rate of epithelial damage to tissues [53]. These findings correlate with clinical studies, which have found increasing host susceptibility to influenza and SARS-CoV with a lower concentration of vitamin A in several disease models [54]. In light of its pulmonary and immunological roles, oral supplementation of vitamin A is currently being investigated in the treatment of COVID-19 alongside a host of other antioxidants [55]. 


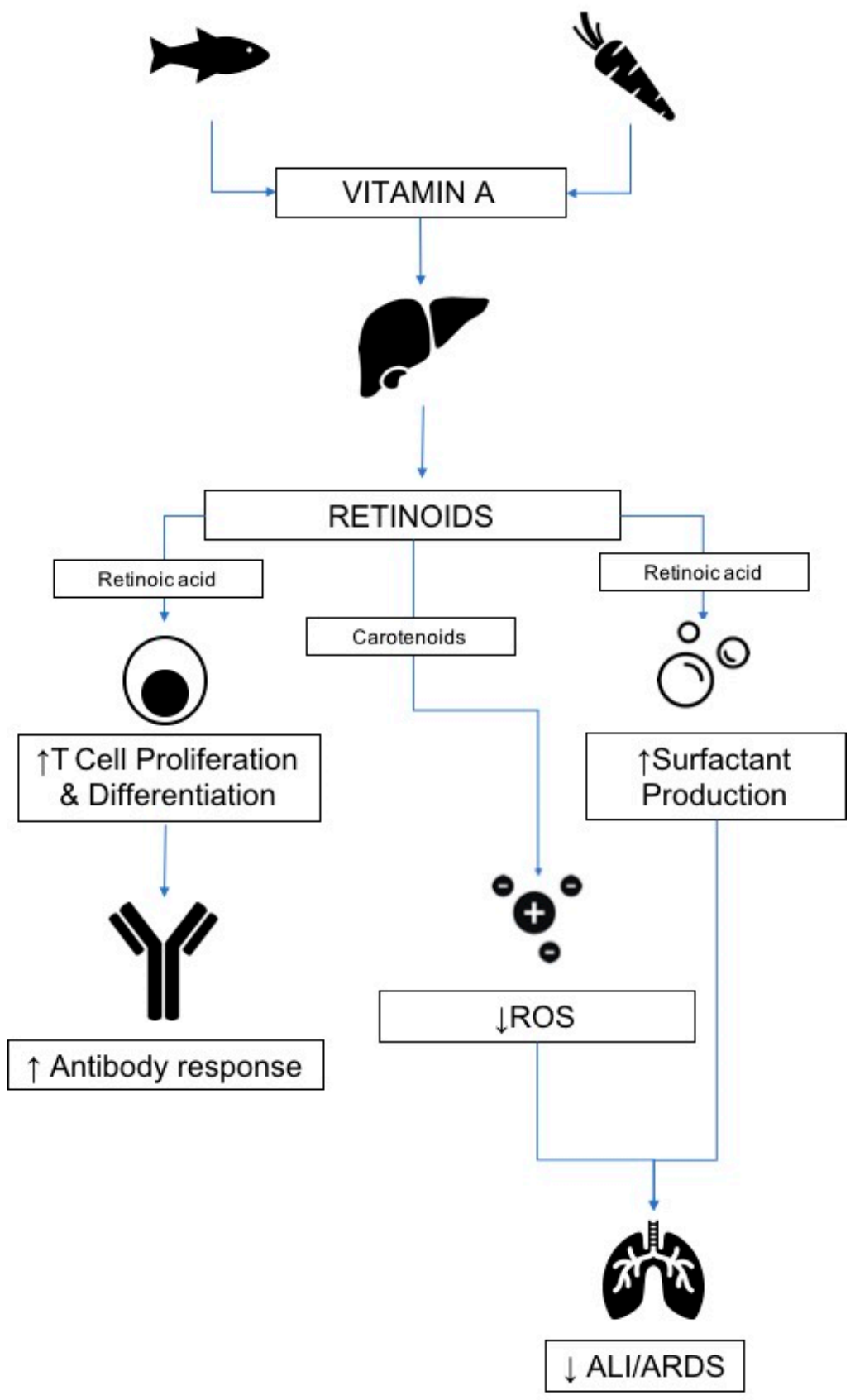

Figure 4. Retinoic acid and carotenoids exert a number of physiological effects, including the augmentation of $\mathrm{T}$ cell function, which may improve the adaptive immune response to pathogens, such as viruses. Furthermore, antioxidant and surfactant-mediating properties of vitamin A derivatives may have a protective role in the pathogenesis of ARDS, a known complication of severe cases of COVID-19.

\subsection{Vitamins $B$}

\subsubsection{Sources and Physiological Role}

$B$ vitamins are a class of water-soluble vitamins $\left(B_{1}, B_{2}, B_{3}, B_{5}, B_{6}, B_{7}, B_{9}\right.$, and $\left.B_{12}\right)$ that play important roles in cell metabolism (Table 1). They are chemically distinct entities but may coexist in the same foods, including meat and plant-based sources. B12 is found predominantly in meat, such as turkey, tuna, and liver, whereas folate is largely present in plant products, such as legumes (pulses or beans), greens, nuts, whole grains, potatoes, bananas, chili peppers, tempeh, and yeast. They are 
also found in small quantities in unprocessed carbohydrates whereas processed carbohydrates, such as sugar and white flour, have lower vitamin B levels, often corrected by supplementation. Dietary supplements containing all eight are referred to as a vitamin B complex.

Studies suggest that vitamin B complex may regulate cytokine/chemokine generation and mediate interaction with immune cells involved in pathophysiological pathways and inflammation [56]. Vitamin $B_{1}$ (thiamine), like other B-complex vitamins, acts as a coenzyme in its phosphorylated forms, contributing to glucose, fat, and protein metabolism, participating in the production of energy for the body. Its deficiency in the nervous system may impair the ability to synthesize fatty acid and cholesterol, necessary for membrane function. With specific regard to inflammation, vitamin $B_{1}$ deficiency in the brain induces overexpression of proinflammatory mediators, such as IL-1, IL-6, COX-2, and TNF- $\alpha$, which cause neuronal cell death in the central nervous system (CNS) damage and neuroinflammation, leading to Wernicke's encephalopathy and an irreversible dementia of Korsakoff's syndrome [57]. Vitamin $B_{2}$ (riboflavin) has immunomodulatory effects, and deficiency upregulates proinflammatory gene expression [56]. Niacin, an amide of $B_{3}$, reduces TNF $\alpha$, IL-6, and IL-1 $\beta$ in stimulated alveolar macrophages and inhibits NF- $\mathrm{KB}$ activation [58]. Similarly, vitamin B7 (biotin) is also recognized as an immunoregulatory vitamin through its effects on proinflammatory cytokine expression [59].

Table 1. Physiological role of the B vitamins.

\begin{tabular}{|c|c|c|c|c|}
\hline B Vitamin & Chemical Name & Chemical Structure & Physiological Role & $\begin{array}{c}\text { Evidence Related } \\
\text { to SARS-CoV-2 } \\
\text { Pandemic }\end{array}$ \\
\hline $\mathrm{B}_{1}$ & Thiamine & & $\begin{array}{l}\text { Precursor of coenzymes in } \\
\text { sugar and amino acid } \\
\text { catabolism }\end{array}$ & $\begin{array}{c}\text { IV thiamine } \\
\text { (together with high } \\
\text { dose vitamin } C \text { and } \\
\text { corticosteroids) } \\
\text { shown to prevent } \\
\text { deaths in people } \\
\text { with sepsis [60] }\end{array}$ \\
\hline $\mathrm{B}_{2}$ & Riboflavin & & $\begin{array}{l}\text { Precursor of coenzymes } \\
\text { needed for flavoprotein } \\
\text { enzyme reactions }\end{array}$ & $\begin{array}{l}\text { Riboflavin (B2) and } \\
\text { UV light effectively } \\
\text { reduced the titer of } \\
\text { MERS-CoV in } \\
\text { human plasma [61] }\end{array}$ \\
\hline $\mathrm{B}_{3}$ & $\begin{array}{l}\text { Niacin (nicotinic } \\
\text { acid), nicotinamide, } \\
\text { nicotinamide } \\
\text { riboside }\end{array}$ & & $\begin{array}{l}\text { Precursor of coenzymes } \\
\text { needed in many metabolic } \\
\text { processes }\end{array}$ & $\begin{array}{l}\text { Nicotinamide } \\
\text { identified to have } \\
\text { potential binding } \\
\text { affinity for the } \\
\text { SARS-CoV-2 } \\
\text { protease [62] }\end{array}$ \\
\hline $\mathrm{B}_{5}$ & Pantothenic acid & & Precursor of coenzyme A & None to date \\
\hline $\mathrm{B}_{6}$ & $\begin{array}{c}\text { Pyridoxine, } \\
\text { pyridoxal, } \\
\text { pyridoxamine }\end{array}$ & & $\begin{array}{l}\text { Precursor of coenzyme in } \\
\text { metabolic reactions }\end{array}$ & None to date \\
\hline $\mathrm{B}_{7}$ & Biotin & & $\begin{array}{l}\text { Coenzyme for carboxylase } \\
\text { enzymes needed for } \\
\text { gluconeogenesis and fatty } \\
\text { acid synthesis }\end{array}$ & None to date \\
\hline
\end{tabular}


Table 1. Cont.

\begin{tabular}{|c|c|c|c|c|}
\hline B Vitamin & Chemical Name & Chemical Structure & Physiological Role & $\begin{array}{c}\text { Evidence Related } \\
\text { to SARS-CoV-2 } \\
\text { Pandemic }\end{array}$ \\
\hline $\mathrm{B}_{9}$ & Folate & & $\begin{array}{l}\text { Precursor needed for DNA } \\
\text { synthesis and repair } \\
\text { especially during rapid } \\
\text { cell division }\end{array}$ & $\begin{array}{l}\text { Folate identified to } \\
\text { have potential } \\
\text { binding affinity to } \\
\text { the SARS-CoV-2 } \\
\text { protease [63] }\end{array}$ \\
\hline $\mathrm{B}_{12}$ & $\begin{array}{l}\text { Cobalamins e.g., } \\
\text { cyanocobalamin, } \\
\text { methylcobalamin }\end{array}$ & & $\begin{array}{c}\text { Coenzyme in metabolic } \\
\text { reactions affecting DNA, } \\
\text { fatty acid and amino acid } \\
\text { metabolism }\end{array}$ & $\begin{array}{l}\text { Vitamin B12 } \\
\text { identified to have } \\
\text { potential binding } \\
\text { affinity to the } \\
\text { SARS-CoV-2 } \\
\text { protease [62] }\end{array}$ \\
\hline & & $R=5^{\prime}$. & & \\
\hline
\end{tabular}

\subsubsection{Mechanism of Action in Disease}

Vitamins $B_{6}, B_{12}$, and folate play important and complementary roles in both innate and adaptive immune responses and have been granted health claims in the European Union for contributing to the normal function of the immune system $[64,65]$. It is not surprising that deficiencies in these vitamins can impair immune functions. Vitamin $\mathrm{B}_{6}$ reduces the function and proliferation of T-lymphocytes and inhibits cytokine/chemokine release [56]. Vitamin $B_{9}$ (folate) deficiency has been reported to lead to megaloblastic anemia, failure to thrive, and infections due to combined immunodeficiency with an impaired T-cell proliferation response, pan-hypogammaglobinemia, and an altered proinflammatory cytokine profile, which are reversed with folate therapy [66]. Vitamin $B_{12}$ (cobalamin) deficiency is particularly common in the elderly due to reduced absorption [67], and induces an imbalance in the cytokine and growth factor network in the CNS. Studies allude to a role in mediating the immune response to viral infection, as supplementation significantly improved sustained viral response rates in patients chronically infected with hepatitis $C$ virus [68].

\subsubsection{Respiratory Disease}

Thiamine acts as a cofactor for pyruvate dehydrogenase, the enzyme necessary for converting pyruvate to acetyl-coenzyme A (acetyl-CoA) for entry into the Krebs cycle. When thiamine levels are insufficient, pyruvate is unable to be converted to acetyl-CoA, resulting in impaired aerobic respiration and a compulsory shift to the anaerobic pathway, resulting in elevated serum lactate [69]. Thiamine and niacin is also needed for the generation of NADPH and glutathione cycling, which is an important antioxidant pathway [70]. These pathways (Figure 5) form the basis of thiamine administration in critically ill populations, which demonstrate reduced lactate and improved mortality in a trial of patients with septic shock [71]. It is of particular relevance that there are a number of studies showing a benefit of thiamine (200 mg every $12 \mathrm{~h}$ ) in combination with vitamin C (1500 mg every $6 \mathrm{~h}$ ) and hydrocortisone (50 mg every $6 \mathrm{~h}$ ) in people with sepsis [60], leading to dramatic improvements in organ injury, time to shock reversal, and mortality [60] as well as severe pneumonia [72]. Fimognari et al. reported lower levels of folate and vitamin B12 in chronic obstructive pulmonary disease (COPD) patients [73], but there is little evidence of the role of supplementation on improving symptoms, hospitalization, or pulmonary function [74]. 


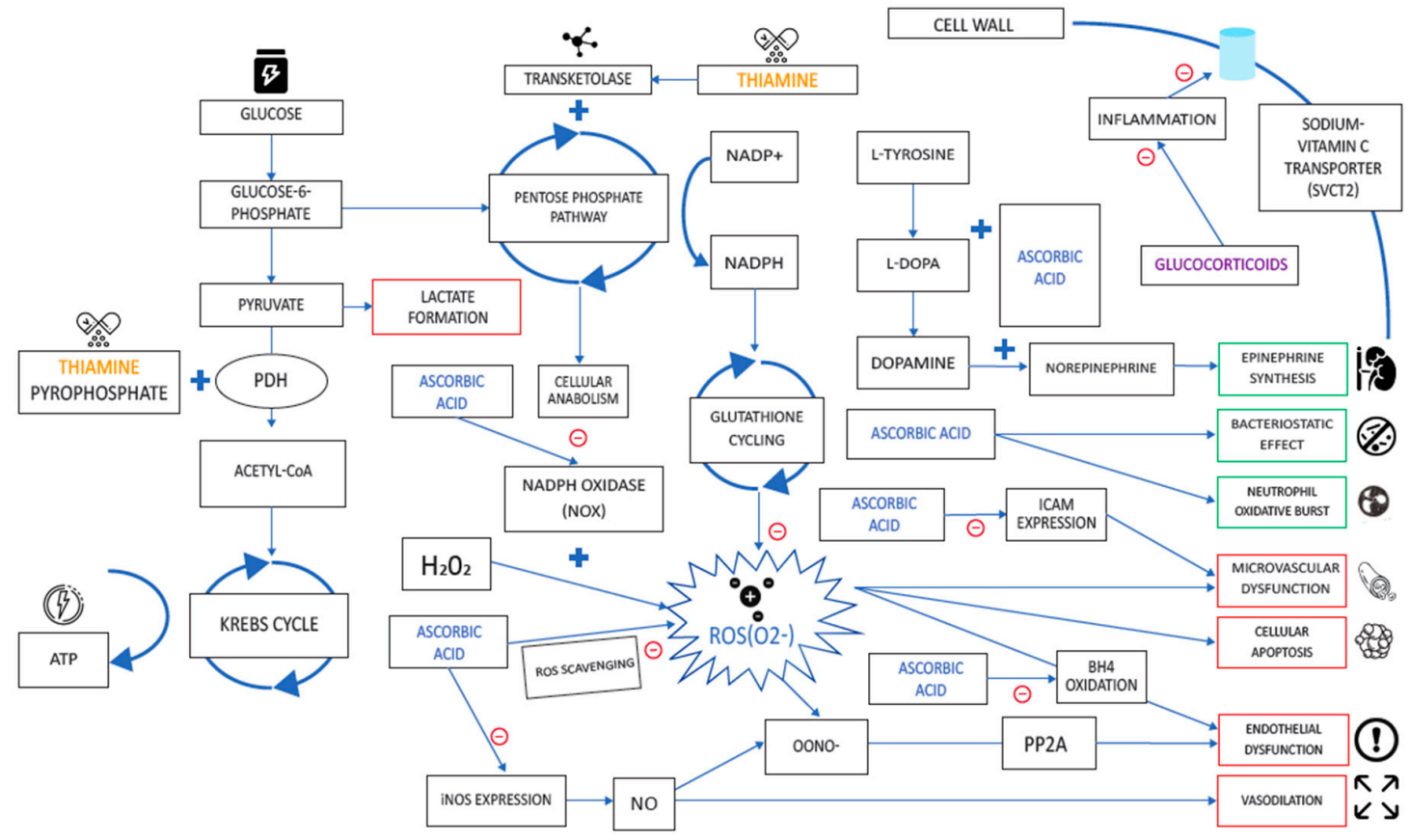

Figure 5. Thiamine and its derivatives act synergistically with ascorbic acid to reduce anaerobic respiration and reduce oxidative stress. It has been suggested this combination may improve mortality and organ recovery in critically ill patients with septic shock through vasoactive effects, bacteriostatic action, and immune cell mediation. The significance of these actions on viral infections, such as COVID-19, remain to be elucidated.

\subsubsection{Relevance to COVID-19}

The coronavirus polyprotein encodes two proteases, called 3-C-like protease (M-pro) and a papain-like protease (PL-pro), which were previous targets for drug discovery in the SARS and MERS coronavirus epidemics [75]. A recent study utilized the available crystal structure of SARS-CoV-2 protein M-pro to screen existing approved drugs to see if they could be repurposed to combat COVID-19 [62,76]. This study, based on docking scores, ligand efficiency, lipophilic, and hydrogen bonding interactions to predict the more powerful binding drugs, found that vitamin $\mathrm{B}_{12}$ and nicotinamide ranked at the fourth and sixth positions, respectively [62]. Another computational study also investigated molecules that are predicted to bind tightly to M-pro in SARS-CoV-2 and identified that folate has the potential to form strong hydrogen bonds with active site residues and therefore be a possible therapeutic strategy [63]. These computational screening tools may allow targeted drug testing to be undertaken using cell-based assays and clinical trials, with niacin $\left(\mathrm{B}_{3}\right)$, folate $\left(\mathrm{B}_{9}\right)$, and $\mathrm{B}_{12}$ being possible contenders. These tools are particularly important in the COVID-19 pandemic, where there is currently no targeted therapeutics and effective treatment options remain very limited.

\subsection{Vitamin C}

\subsubsection{Source and Physiological Role}

Vitamin C, also known as ascorbic acid (Figure 6), is an essential water-soluble nutrient, required as a cofactor for a number of enzymatic reactions required in norepinephrine biosynthesis, amidation of peptide hormones, collagen hydroxylation, hypoxia-inducible factor (HIF) hydroxylation, regulation of HIF, carnitine biosynthesis, tyrosine metabolism, and histone demethylation [77]. Its effects on the immune system during infection is wide ranging and includes the promotion of phagocytosis and chemotaxis of leucocytes and development and maturation of T-lymphocytes. It also has an important homeostatic antioxidant role, whereby phagocytes import oxidized vitamin C, (dehydroascorbic acid) 
and reduced vitamin C (L-ascorbic acid) is regenerated in exchange [78,79]. There is also speculation that vitamin $\mathrm{C}$ may play a role in mediating the adrenocortical stress response, particularly in sepsis [80].

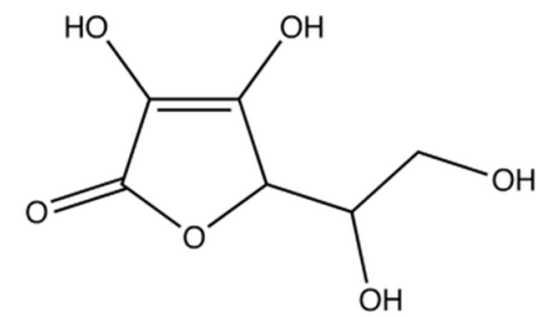

Figure 6. Chemical structure of vitamin C, ascorbic acid.

\subsubsection{Mechanism of Action in Disease}

Vitamin $C$ has been proposed as a treatment for respiratory infections ever since it was first synthesized in 1933 [81]. The Nobel laureate, Linus Pauling, concluded from early randomized controlled trials (RCTs) that vitamin C prevented and alleviated the common cold and as such popularized its use in the 1970s [82,83]. It is postulated to exert an antiviral effect through direct virucidal activity and augmenting interferon production whilst also having effector mechanisms in both arms of the innate and adaptive immune system [84-86]. The host response to viruses and bacteria include the release of reactive oxygen species (ROS) from activated phagocytes. Paradoxically, this has been shown to be harmful to host cells and in some cases is implicated in the pathogenesis of viral and bacterial infections [87-89]. Animal studies support a beneficial role of vitamin $C$ in reducing the incidence and severity of bacterial and viral infections [90]. These positive effects include increased resistance of chick embryo tracheal organ cultures to infection and protecting broiler chicks against avian coronavirus [91,92]. The relationship between oxidative stress and the induction of genes integral to the systemic inflammatory response, including TNF $\alpha$, IL-1, IL-8, and ICAM-1, has been shown to be mediated through activation of the nuclear transcription factor NF- $\mathrm{B}$ [93-95]. Vitamin $\mathrm{C}$ has been shown to reduce inflammation and ROS via attenuation of NF-kB activation [96].

\subsubsection{Respiratory Disease}

Vitamin $\mathrm{C}$ is generally considered safe; however, reported adverse effects of high-dose intravenous vitamin C (HDIVC) include oxalate kidney stone production $[97,98]$. Its potential benefits, low cost, and safety profile make it an attractive therapeutic candidate in treating respiratory infections. A Cochrane review examining placebo-controlled trials testing $200 \mathrm{mg} /$ day or more of oral vitamin C for preventing and treating the common cold found that supplementation did not reduce incidence in the general population [99], but doses of 6-8 g/day were associated with a shorter duration and severity of common cold symptoms with $46 \%$ symptom-free within 24 hours on an $8 g$ dose [100]. A subgroup analysis of heavy acute physical stress trials did find that it halved the incidence in this population [101-104]. Based on these findings, vitamin C may be useful for people exposed to brief periods of severe physical exercise or in high doses for those with active cold symptoms. This work has led to the investigation of vitamin $C$ as a candidate treatment to offset the effects of inflammation and oxidative stress seen in sepsis and ARDS. Excessive generation of potent proinflammatory cytokines and chemokines soon after the onset of sepsis sets the stage for the development of multi-organ failure (MOF) [105]. The cytokine storm can result in neutrophil migration and accumulation within the lung interstitium and bronchioalveolar space and is regarded a key determinant of progression in ARDS [106]. Neutrophil extracellular traps or NETosis is a cell death pathway different from apoptosis and necrosis that traps and kills pathogens [107]. An excessive NETosis response is a maladaptive response that leads to tissue injury, organ damage, and contributes to MOF. There is evidence to suggest that vitamin $C$ is a novel regulator of this process [108]. Furthermore, vitamin $C$ had been shown to significantly decrease serum TNF $\alpha$ and IL-1 $\beta$ levels and increased superoxide dismutase, catalase, and glutathione levels 
in a rat ARDS model supporting its antioxidant effect [109]. Additionally, vitamin C also enhances lung epithelial barrier function by promoting epigenetic and transcriptional expression of protein channels at the alveolar capillary membrane that regulate alveolar fluid clearance, which include aquaporin-5, cystic fibrosis transmembrane conductance regulator, epithelial sodium channel, and the $\mathrm{Na}^{+} / \mathrm{K}^{+}$-ATPase pump [110].

Vitamin C bioavailability is $100 \%$ for a single oral $200 \mathrm{mg}$ dose but decreases to $33 \%$ with a single $1250 \mathrm{mg}$ dose in a healthy individual [111]. Additionally, inflammatory cytokines negatively regulate an isoform of the sodium-dependent vitamin C transporter (SVCT2), which results in depletion of intracellular vitamin C [112]. Limitations in bioavailability coupled with consumption of vitamin $\mathrm{C}$ seen in severe infection have led to the hypothesis that therapeutic plasma levels to mitigate the degree of oxidative stress generated in critically unwell patients cannot be achieved with oral administration $[113,114]$. In the largest trial investigating the role of high-dose $(50 \mathrm{mg} / \mathrm{kg}$ every $6 \mathrm{~h}$ for 4 days) intravenous vitamin C in sepsis-associated ARDS, the CITRIS-ALI trial, patients in the high-dose group did not significantly improve organ dysfunction scores or markers of inflammation and vascular injury [115]. However, mortality, while a secondary outcome, was dramatically reduced among the patients receiving vitamin C. Other authors have commentated how statistics may have been used to obfuscate the true findings of the study and thus confounding factors in that trial methodology potentially exist [116]. A meta-analysis of intravenous vitamin $C$ supplementation in the critically ill (burns, sepsis, and septic shock) patients found that it may lead to vasopressor sparing effects, a reduced duration of ITU stay, and a reduced need for mechanical ventilation in the critically ill, without affecting overall mortality $[117,118]$. Combination therapies exist and consist of vitamin $C$ along with enteral omega-3 fatty acid, $\gamma$-linolenic acid, steroids, thiamine, and antioxidants $[119,120]$. System biology analysis has also identified vitamin $C$ in combination with curcumin, and glycyrrhizic acid acts on multiple hub targets closely connected and associated with immune and inflammatory responses, warranting in vitro and in vivo investigation [121]. However, these other compounds potentially confound the effect of vitamin $C$ alone and therefore are not appraised here. Other RCTs of HDIVC in progress include the Vitamin C, Thiamine, and Steroids in Sepsis (VICTAS) trial [122]. Clearly, further carefully designed RCTs are needed to evaluate the potential role of vitamin $C$ for other outcomes in sepsis and ARDS before supplementation is considered as a standard of care.

\subsubsection{Relevance to COVID-19}

Given the potential role of vitamin C in sepsis and ARDS, there is gathering interest of whether supplementation could be beneficial in COVD-19 [123-125]. Research is gathering pace, with an HDIVC cohort study in progress in Palermo, Italy [126]. Recruitment has also begun on a new clinical trial investigating vitamin C infusion for severe 2019-nCoV-infected pneumonia in Wuhan, China. This is the first RCT to test whether there is a benefit of HDIVC in COVID-19. One-hundred and forty patients are planned to be treated with a placebo or HDIVC at a dose of $24 \mathrm{~g} /$ day for 7 days [127]. Despite what we know about the antioxidant properties, antiviral effect, and pleiotropic function of vitamin C, whether or not there are beneficial pathophysiological mechanisms involved in the response to COVID-19 remain to be elucidated [128]. Given the favorable safety profile of vitamin C, current treatment is potentially justified with compassionate use until COVID-19 data becomes available.

\subsection{Vitamin D}

\subsubsection{Source and Physiological Role}

Vitamin D (Figure 7) encompasses a number of fat-soluble secosteroids with a physiological role in mineral homeostasis, primarily calcium, magnesium, and phosphate. As such, deficiencies in vitamin $\mathrm{D}$ have been implicated in a number of metabolic bone diseases, such as osteoporosis, osteomalacia, and rickets [129]. Vitamin D in its natural form, cholecalciferol, is acquired through dietary sources, such as oily fish and egg yolks, but is also produced through de novo synthesis in the 
stratum basale and stratum spinosum of the epidermis using dehydrocholesterol in the presence of ultraviolet $B$ (UVB) radiation. Cholecalciferol is thereafter hydroxylated into its biologically active forms 25-hydroxyvitamin D (calcifediol) and 1,25-dihydroxyvitamin D (calcitriol) [130].

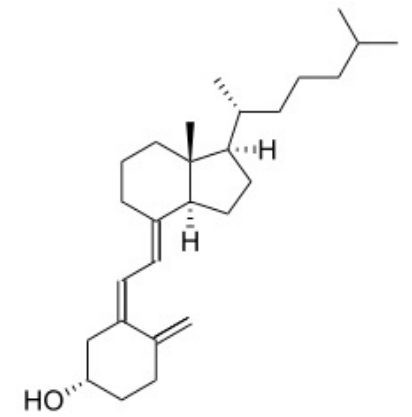

Figure 7. Chemical structure of vitamin D3, cholecalciferol.

In addition to its well-recognized roles in calcium and bone homeostasis, the physiological roles of vitamin D also include immunomodulation and in critically ill patients [131], and there are well-documented associations between vitamin D deficiency and infection rates [132], renal and respiratory failure [133,134], sepsis [135], and mortality [136]. There have been a number of studies in which an association between vitamin D deficiencies have also been associated with immunological disorders, such as multiple sclerosis [137], ulcerative colitis [138], Crohn's disease [139], and asthma [140].

Vitamin D deficiency is believed to affect one billion people worldwide [141]. At particular risk are individuals with darker skin, as the increased levels of pigmentation hinder the penetration of ultraviolet (UV) light needed for epidermal vitamin D synthesis. Additional at-risk groups include the elderly, who are often deficient in vitamin D, compounded by increased time indoors, reduced epidermal synthesis, and impaired vitamin D metabolism with some pharmaceutical agents, such as antihypertensives and antiepileptics [142]. Furthermore, as our knowledge of the causality of UV light exposure and the development of skin cancer and skin ageing has deepened, our behaviors have necessarily adjusted to minimize our exposure to UV light, with protective clothing and solar protective factors becoming more commonplace over the course of the last century. A sun cream with a sun protection factor (SPF) of only 8 is sufficient to reduce epidermal vitamin D synthesis by 95\% [143]. As vitamin $\mathrm{D}$ is so difficult to acquire through dietary means, and especially challenging to acquire through sunlight in the autumn and winter months, many commonplace foods are now fortified with vitamin D. Nonetheless, Public Health England recommended in 2016 that a daily supplement of $10 \mu \mathrm{g}$ vitamin D should be considered for all during the autumn and winter months to minimize the risk, and consequences, of deficiency [144].

\subsubsection{Mechanism of Action in Disease}

Beyond its role in mineral homeostasis, recent research has emerged regarding the potential role of vitamin $\mathrm{D}$ as an immune system regulator. With regard to infectious and immune etiology, vitamin $\mathrm{D}$ has been linked to increased severity of numerous viral infections, including human immunodeficiency virus (HIV) [145,146], and for certain bacterial infections, including TB [147]. Supplementation with vitamin $\mathrm{D}$ has also been reported previously as reducing the risk of acute upper respiratory tract infections, which has led to speculation that there may be a role for vitamin $\mathrm{D}$ in the response to COVID-19 [36,148].

It has been hypothesized that vitamin $\mathrm{D}$ exerts its antimicrobial effects in three main ways: Through augmenting natural protective barriers, enhancing innate cellular immunity, and boosting adaptive immunity [149]. With regard to reinforcing natural barriers, vitamin D has been implicated in the preservation of tight junctions, gap junctions, and adheren junctions between epithelial cells, 
the disruption of which is a pathogenic mechanism of upper respiratory tract viruses, such as respiratory syncytial virus [150,151]. Specifically, with regard to COVID-19, correction of vitamin D deficiency is thought to suppress CD26/DDP4, one of the adhesion molecules through which the closely related COVID-MERS virus and indeed the COVID-19 virus is believed to acquire access to host cells [152-154]. Should the virus successfully invade the host, the next immunological barrier is the innate immune system. Vitamin D has been shown to enhance innate immunity through promoting the release of defensins and cathelicidins, the latter of which have demonstrated direct antimicrobial effects against enveloped and non-enveloped viruses $[155,156]$. Vitamin D also has been shown, in both animal data and clinical data, to be linked to reduced viral replication [157].

Of further significance is the role of vitamin D in mediating the inflammation that underlies ALI and ARDS. Vitamin D deficiency in particular has been recognized as a direct contributor to ARDS in the aftermath of bacterial sepsis, major surgery, and non-cardiogenic respiratory failure [158-160]. Vitamin D is believed to stimulate Th2 cells and regulatory T cells yet attenuate Th1 cells. This leads to a reduction in the release of proinflammatory cytokines, such as TNF $\alpha$ and IFN $\gamma$, by Th1 cells, which is believed to contribute to the pathogenesis of ARDS [161-163]. Vitamin D also upregulates the expression of some antioxidant genes, such as glutathione reductase, reducing the free radicals generated in inflammation, which are believed to contribute to the pulmonary damage that leads to the development of ARDS [164].

\subsubsection{Respiratory Disease}

Specifically, with regard to pulmonary physiology, it has been demonstrated in animal models that vitamin D attenuates microbial ALI and ARDS through modulating the expression of the renin-angiotensin system (RAS), including ACE 1 and 2 [165]. One of the key pathogenic mediators of microbial-induced ALI is the increase in alveolar capillary membrane permeability, which evokes pulmonary oedema, hypoxemia, and pulmonary hypertension. The respiratory epithelium is able to convert vitamin $\mathrm{D}$ to its active form as part of local paracrine and autocrine signaling pathways implicated in host defense [166]. ACE2 enzyme inactivates angiotensin II, and as such acts as a negative regulator of the RAS. As such, ACE2 has been deemed protective against the development of ARDS, with animal models suggesting a key role in regulating vascular permeability, lung oedema, and oxygenation [167]. In a rat model of ARDS, calcitriol was demonstrated to upregulate pulmonary ACE2 and downregulate renin and angiotensin II, indicating there may be a key mechanistic role for vitamin D in hindering the progression of infection-induced ARDS [165]. Results from a meta-analysis of vitamin D supplementation and risk of acute (bacterial and viral) respiratory tract infection show a $12 \%$ overall protective effect of vitamin D supplementation. This increased to $19 \%$ with a daily or weekly regimen compared to a monthly bolus regimen. Furthermore, a $70 \%$ protective effect was observed when deficiency was corrected [168].

\subsubsection{Relevance to COVID-19}

This picture is confounded somewhat in the case of COVID-19, which acquires entry to cells through binding to ACE2 [1]. However, the binding of the viral S1 spike protein to ACE2 causes both the virus and the enzyme to be translocated into the cell through endocytosis, thereby effectively reducing the surface expression of ACE2 and possibly contributing to the progression of pulmonary disease [169]. There does appear to be associations between high levels of ACE2 and survival benefit, implicating the attenuation of the RAS system as a means of protection against ARDS [170]. Ethnic variations in the expression of ACE2 receptors have also been noted, with the highest expression seen in East Asian males [171]. The ethnic disparities in ACE2 expression and polymorphisms may be a contributor to disease severity either independently or in conjunction with vitamin D status, and warrants further investigation. Additionally, the higher preponderance of male:female sex-specific COVID-19 mortality may in part be related to hormonal dependency of expression and/or activity of ACE2 seen in animal studies [172]. The effects of severe vitamin D deficiency have been explored in 
humans: Following the inhalation of bacterial cell wall constituent, lipopolysaccharide (LPS), a marked increase in alveolar inflammation (IL-1B) was noted in vitamin D-deficient individuals compared to those with mild deficiency [173]. Specifically, there has been increasing speculation that vitamin D deficiency may underpin the likelihood of mortality and disease severity in COVID-19 [125,174-189]. Observed differences in COVID-19 mortality between the northern and southern hemispheres also add to the case for vitamin D having a role in the pathogenesis of COVID-19 [190]. The emergence of Brazil as a disease hotspot may change these findings in time. Crude pan-European analysis, however, showed a negative correlation between mean levels of vitamin $\mathrm{D}$ in each country and the number of COVID-19 cases and mortality [191,192]. These associations, along with the physiological and immunological roles of vitamin D summarized in Figure 8, have prompted clinical trials in vitamin D supplementation in COVID-19 patients and warrant further mechanistic investigation [193,194].

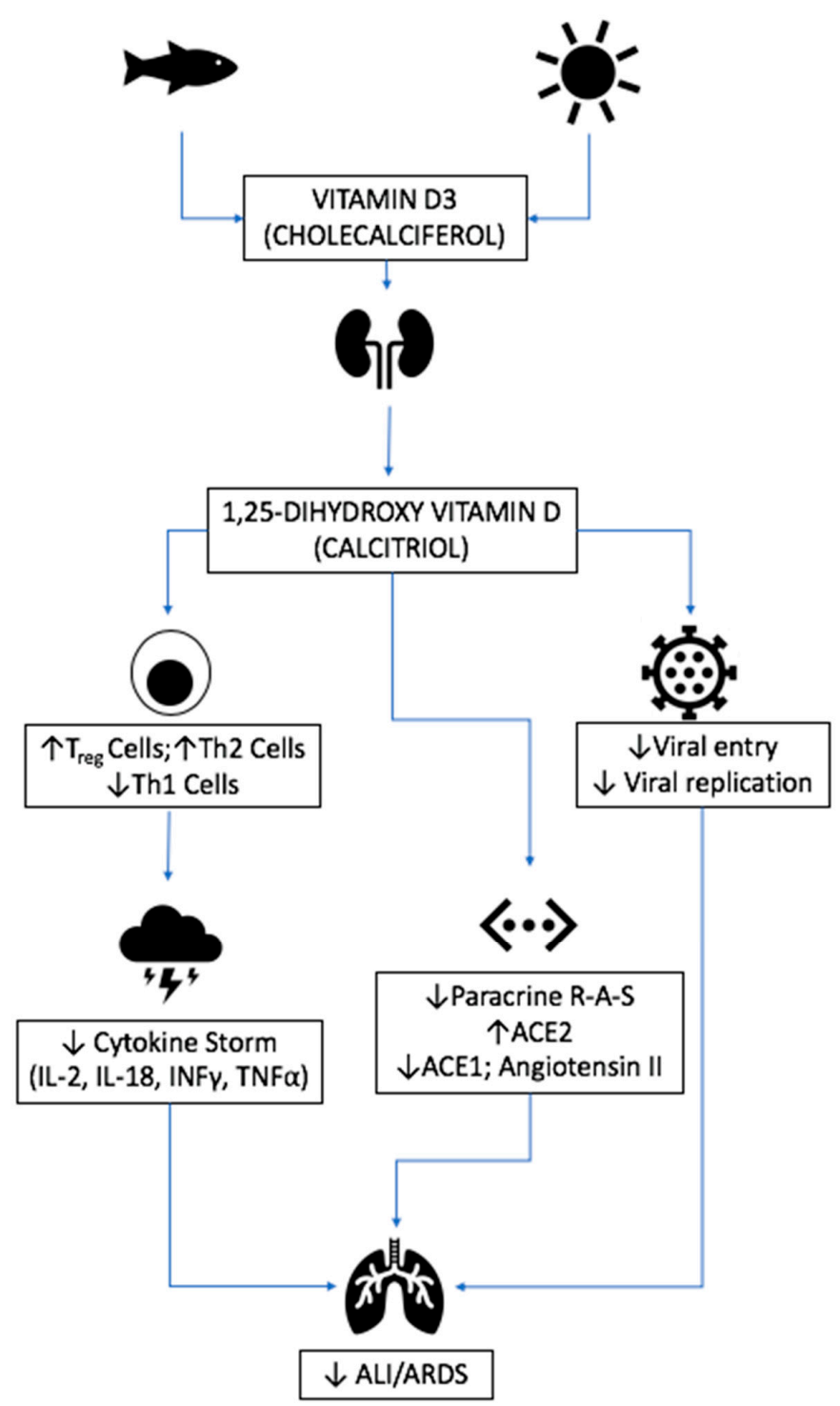

Figure 8. Vitamin D and potential anti-COVID19 mechanisms of action. Vitamin D derivatives are thought to mediate the immune system responses to infective agents through enhanced Treg and Th2 cell function, attenuating the cytokine storm that is thought to be a key pathogenic mechanism in ARDS. Other speculated roles include the protection against lung injury through modulating the pulmonary renin-angiotensin system and reducing viral entry and replication. 


\subsection{Vitamin E}

\subsubsection{Source and Physiological Role}

Vitamin $E$ is fat-soluble compound, which consists of eight isoforms, four tocopherols $(\alpha-, \beta-, \gamma$, and $\delta$-tocopherols), and four tocotrienols ( $\alpha-, \beta-, \gamma-$, and $\delta$-tocotrienols), and it is a lipid component of biological membranes. The various isoforms are not interchangeable and only $\alpha$-tocopherol meets the human vitamin E requirements. The main source in human diet varies depending on the isoform, with $\alpha$-tocopherol found predominantly in sources, such as nuts like almonds and hazelnuts; legumes, such as peanuts; as well as avocados and sunflower seeds.

Vitamin $\mathrm{E}$ is absorbed via the small intestine and metabolized, regulated, and excreted by the liver. Vitamin $\mathrm{E}$ as $\alpha$-tocopherol, and to a lesser degree tocotrienols, is processed by the liver by $\alpha$-tocopherol transfer protein into chylomicrons [195] that are transported to tissues in the lymphatic system [196]. Although $\alpha$-tocopherol is the main biologically active isoform, some evidence has shown that tocotrienols have a more potent antioxidant effect in neutralizing peroxyl radicals and lipid peroxidation in rat models; however, owing to its lesser bioavailability, less than $3 \%$ of research has focused on the tocotrienol isoforms [197-199].

\subsubsection{Mechanism of Action in Disease}

Vitamin $\mathrm{E}$ is considered a potent antioxidant capable of neutralizing free radicals and ROS by donating a hydrogen ion from its chromanol ring (Figure 9). Free radicals generated from metabolic processes react with polyunsaturated fats within the cell membrane, causing peroxidative decomposition [200]. Vitamin E deficiency results in greater levels of lipid peroxidation in both in vivo and in vitro models and this is supported clinically by an inverse relationship between plasma lipoperoxidase and vitamin E in ARDS patients [201-203].

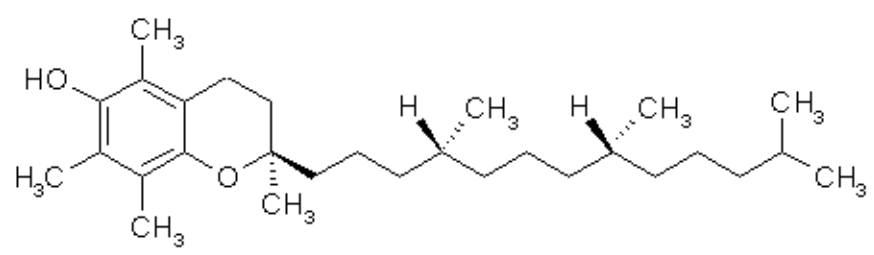

Figure 9. Chemical structure of vitamin $E,\left(2^{\prime} R, 4^{\prime} R, 8^{\prime} R\right)$-tocopherol.

Vitamin E has been shown to enhance the immune response both in animal and human models through the following mechanisms: (1) Decreased production of nitrogen oxide resulting in prostaglandin E2 downregulation and inhibition of cyclooxygenase-2, (2) initiation of T-lymphocyte signals, and (3) modulation of the Th1/Th2 balance (Figure 10) [204].

An additional immunomodulatory effect of vitamin $\mathrm{E}$ is actioned through protein kinase $\mathrm{C}$ (PKC). Inhibiting PKC has been shown to affect the proliferation of monocytes, macrophages, neutrophils, and smooth muscle cells, and reduce superoxide free radical production in neutrophils and macrophages [205]. 


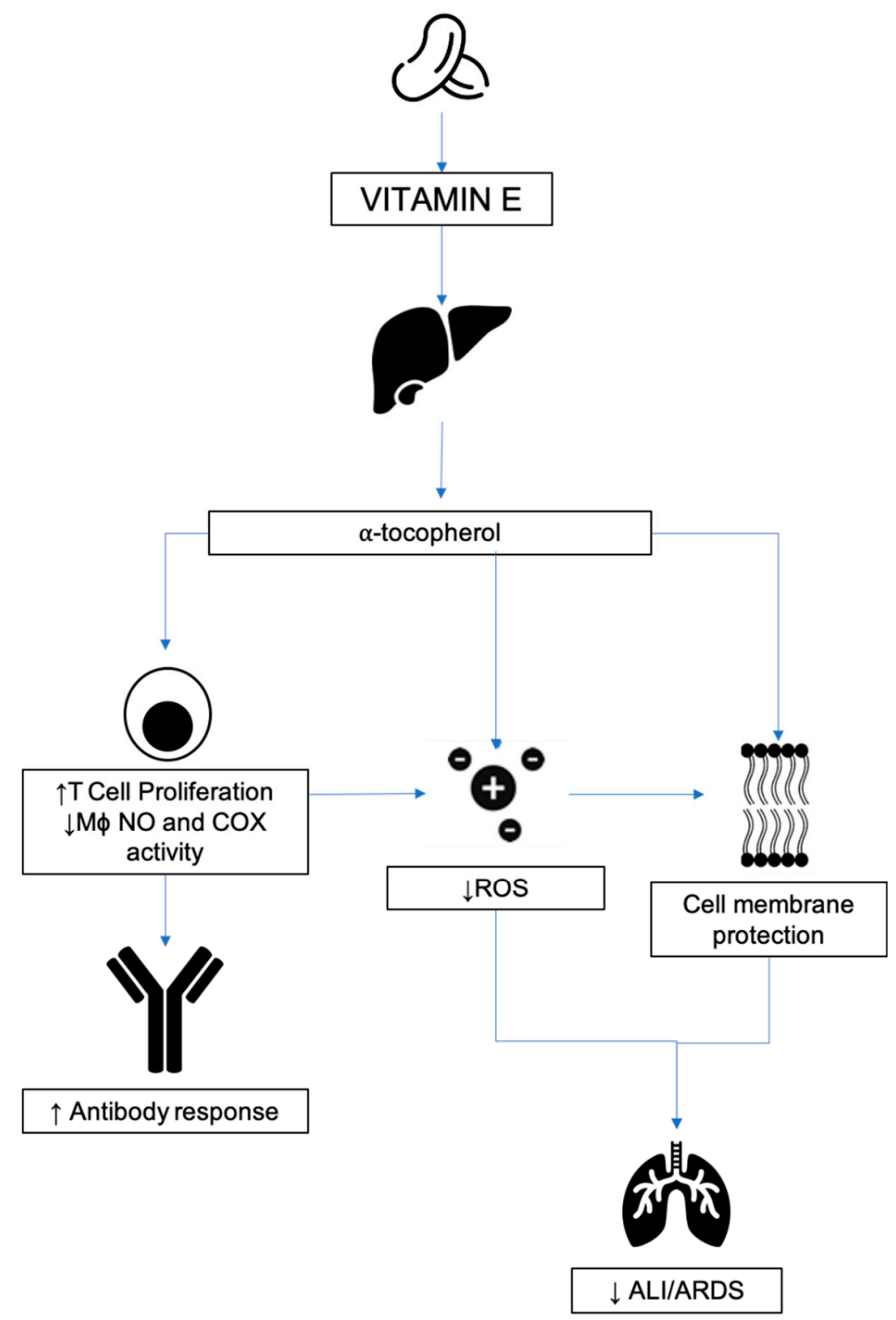

Figure 10. Vitamin E and potential anti-COVID19 mechanisms of action in ARDS. The antioxidant properties of Vitamin E derivatives may augment cell membrane integrity and improve the adaptive immune system response to viral respiratory tract infections.

\subsubsection{Respiratory Disease}

Clinical trials have shown some benefit in relation to vitamin E supplementation and upper respiratory tract infections. Randomization of 617 nursing home residents receiving $200 \mathrm{IU}$ per day for a year of vitamin $E$ showed a reduced incidence of upper but not lower respiratory tract infections [206]. ARDS is characterized by the acute onset protein rich pulmonary edema. The initial phase of the pathological mechanism is referred to as the exudative phase [207]. Complement activation results in upregulation of granulocytes, releasing ROS [208]. When liberated, these ROS result in lipid peroxidation in cell membranes, resulting in increased permeability and loss of integrity. This has been demonstrated in lung parenchyma, resulting in increased protein permeability. High thiobarbituric acid reactive substances (TBARS), an indicator of plasma lipid peroxidation, and low $\alpha$-tocopherol levels have been recognized previously in critically ill patients [209]. One study specifically examined the tocopherol level as related to plasma total lipid (tocopherol:lipid ratio), to control for the dependency of plasma tocopherol concentrations on the level of circulating lipids, and showed a specific deficiency 
in ARDS patients as compared to non-ARDS patients [210]. It is stipulated that a combination of excessive ROS formation and lipoperoxidation during ARDS and septicemia result in a consumptive loss of vitamin $\mathrm{E}$ due to its antioxidant effect. In a rabbit albumin microembolization ARDS model, enteral $\alpha$-tocopherol in vegetable oil versus enteral vegetable oil control significantly improved lung compliance and gas exchange and demonstrated dose-dependent effects on vascular permeability and pulmonary artery pressure. Other animal models have demonstrated similar results with aerosolized $\alpha$-tocopherol [211,212]. However, no randomized controlled trials were identified that met the focus of this review [213].

\subsubsection{Relevance to COVID-19}

COVID-19, as with most viral respiratory infections, has a predilection for those that are immunosuppressed, those with chronic ailments, and the elderly. Immunosenescence refers to the gradual deterioration of the immune system with age. Vitamin $\mathrm{E}$ has been illustrated to enhance $\mathrm{T}$ lymphocyte-mediated immune function in response to mitogens and IL-2 but also neutrophil and natural killer function, the decline of which is seen with increasing age [206,214-216].

Oxidative stress is one of the driving pathological mechanisms that underpins the biology of ARDS as a result of COVID-19. The oxidant-antioxidant balance is severely shifted, resulting in excessive lipid peroxidation and failure of biological membranes. The diffuse alveolar damage, hyaline membrane formation, and pulmonary edema are the pathological outcomes seen in the most severely affected $[217,218]$. Vitamin E ingestion is known to lower the production of superoxides and perhaps tilt the balance back in favor of antioxidants. Deficiency in animal models has also been shown to cause increased genetic mutations that promote the virulence of coxsackievirus, and influenza virus, and two RNA viruses, such as COVID-19 [65,219].

As global efforts turn towards the production of a vaccine, vitamin E supplementation may enhance vaccine efficacy in those most susceptible within our society as seen with increased tetanus antibody titers [214]. Highly complex mechanisms underpin the biological effects of vitamin E and as the pandemic evolves further research may unravel the potential benefits.

\section{Conclusions}

In the absence of a vaccine, the world is eagerly awaiting a panacea of treatment options for COVID-19. In this article, we critically appraised the potential immunomodulatory, antioxidant, and antimicrobial roles of vitamins A to E. Although there is currently no evidence from completed randomized controlled trials to conclusively and specifically demonstrate a role for vitamin supplementation in the fight against COVID-19, there is strong scientific evidence, based on studies of vitamin physiology, pharmacology, and their role in clinical studies of infection and ARDS to indicate a role for vitamins in the battle against this global pandemic. In particular, disease models of a lower vitamin A concentration and increasing host susceptibility to influenza and SARS-CoV have prompted investigation into the relationship between oral supplementation with vitamin A and COVID/COVID-like viruses. Furthermore, computational screening tools is a novel approach revealing promise for targeted drug testing of $\mathrm{B}$ vitamins, such as folate and $\mathrm{B}_{12}$, and supplementation if warranted. Vitamin C, owing to its potential role in attenuating upper respiratory tract infections, its antioxidant properties, and use as a high-dose intravenous therapy in ARDS and sepsis, may prove beneficial in COVID-19. The RCTs currently underway might indeed demonstrate a role for this vitamin in the intensive care setting. The Front Line COVID-19 Critical Care (FLCCC) Working Group released the MATH+ protocol in April 2020 and included vitamin C within its multimodal therapeutic strategy. The protocol consists of intravenous methylprednisolone, high-dose intravenous ascorbic acid, full-dose low-molecular-weight heparin and optional treatment components (including thiamine, zinc, and vitamin D) [220]. This is an early intervention protocol directed at suppressing hyperinflammation seen in COVID-19. Anecdotal experience with this regime has shown that early provision (within $6 \mathrm{~h}$ of admission) of MATH+ has reduced the need for mechanical ventilation and improved mortality rates 
within North America and China. The FLCCC working group are reporting 2 deaths in 100 patients treated with the MATH+ protocol; however, they did not compare their results to a control group. These findings are striking, but larger series and tightly defined indications will be required before widespread adoption of this treatment can be advocated. The vitamin receiving the most publicity at present is vitamin $\mathrm{D}$ in light of the association between disease severity and populations at risk of vitamin D deficiency, the elderly and black, Asian, and minority ethnic (BAME) populations [221]. There is certainly emerging and existing evidence to postulate a mechanism through which this vitamin might play an essential role in the fight against COVID-19, including its association with the pulmonary renin-angiotensin system. The therapeutic potential of vitamin $\mathrm{D}$ has already captured the attention of the scientific and medical communities as evidenced through a number of emerging clinical trials and journal articles. The interest has even percolated through to government [222], with the United Kingdom now advocating the supplementation of vitamin D for individuals in minority ethnic groups, over 65s, and those confined to life indoors [223-226]. However, UK Biobank analyses of blood calcifediol concentration and COVID-19 risk contradicts existing data and government advice. Despite the calcifediol concentration being lower in BAMEs, the study failed to demonstrate an association between calcifediol and COVID-19 infection after adjusting for potential confounders [227].

It would be unjustified to claim that vitamins are the answer to the coronavirus pandemic, but it would be fair to say that there is emerging evidence that they may play a role in either preventative measures or supportive therapy in established respiratory infections and intensive care settings. The physiology, pharmacology, and basic science behind vitamins A to E does allude to potential benefits that warrant further investigation and completion of the clinical trials, even if this translates to a need for diligent deficiency correction rather than routine mass supplementation.

The current and emerging guidance to supplement at-risk populations with vitamin $\mathrm{D}$ is justified given the as of yet unexplained predisposition for the elderly and BAME communities to have the most severe outcomes, potentiated by the fact that an increasing number of individuals will be confined to a life indoors during the lockdown period of the COVID-19 pandemic. Caution must, however, be exercised when recommending vitamin supplementation on a larger scale: The effects of hypervitaminosis can be severe, particularly the fat-soluble vitamins A, D, and E. Of note, hypervitaminosis is almost exclusively a product of ingesting an excess of vitamin supplements, rather than a product of vitamins acquired through normal dietary and physiological means.

The value of maintaining a diet containing a balance of vitamins seems prudent and applicable to the general population during these unprecedented times. We hope in the near future that well-designed clinical trials provide the evidence needed to determine whether the clinical value of vitamins matches the promise of their antioxidative, antimicrobial, and immunomodulatory properties.

Author Contributions: Conceptualization, I.S.W.; methodology, investigation, data curation and writing-original draft preparation, T.H.J., S.R.A., N.I., Z.M.J., S.P.T., T.D.D., P.H., C.A.T. and I.S.W.; writing-review and editing, T.H.J., S.R.A., P.H., C.A.T. and I.S.W.; visualization, T.H.J., S.R.A.; supervision, I.S.W.; project administration, T.H.J., S.R.A. and I.S.W.; funding acquisition, Z.M.J. and I.S.W. All authors have read and agreed to the published version of the manuscript.

Funding: There was no specific funding for this project. The Medical Research Council supported open access publishing for this study (grant number: MR/N002431/1) (Z.M.J.). The Reconstructive Surgery \& Regenerative Medicine Research Group is supported by Microtia UK (T.H.J. and I.S.W.), Action Medical Research (T.H.J.), the Vocational Training Charitable Trust Foundation (T.H.J.), the Welsh Clinical Academic Training Programme (T.H.J., S.R.A., Z.M.J. and T.D.D.), American Association of Plastic Surgeons/European Association of Plastic Surgeons Academic Scholarship (I.S.W.).

Acknowledgments: The authors would like to thank Rhys Whelan, Library Services Manager, Swansea Bay University Health Board, Morriston Hospital, Swansea SA6 6NL, UK for his support with the database searches.

Conflicts of Interest: The authors declare no conflict of interest. 


\section{References}

1. Lu, R.; Zhao, X.; Li, J.; Niu, P.; Yang, B.; Wu, H.; Wang, W.; Song, H.; Huang, B.; Zhu, N.; et al. Genomic characterisation and epidemiology of 2019 novel coronavirus: Implications for virus origins and receptor binding. Lancet 2020, 395, 565-574. [CrossRef]

2. Duffy, S. Why are RNA virus mutation rates so damn high? PLoS Biol. 2018, 16, e3000003. [CrossRef]

3. Wu, Z.; McGoogan, J.M. Characteristics of and important lessons from the coronavirus disease 2019 (COVID-19) outbreak in China. JAMA 2020, 323, 1239-1242. [CrossRef]

4. World Health Organisation. Coronavirus Disease (COVID-19) Pandemic. Available online: https://www. who.int/emergencies/diseases/novel-coronavirus-2019 (accessed on 21 August 2020).

5. Zhou, F.; Yu, T.; Du, R.; Fan, G.; Liu, Y.; Liu, Z.; Xiang, J.; Wang, Y.; Song, B.; Gu, X.; et al. Clinical course and risk factors for mortality of adult inpatients with COVID-19 in Wuhan, China: A retrospective cohort study. Lancet 2020, 395, 1054-1062. [CrossRef]

6. Wrapp, D.; Wang, N.; Corbett, K.S.; Goldsmith, J.A.; Hsieh, C.L.; Abiona, O.; Graham, B.S.; McLellan, J.S. Cryo-EM structure of the 2019-nCoV spike in the prefusion conformation. Science 2020, 367, 1260-1263. [CrossRef] [PubMed]

7. Chen, Y.; Li, L. SARS-CoV-2: Virus dynamics and host response. Lancet Infect. Dis. 2020, 20, 515-516. [CrossRef]

8. U.S. National Library of Medicine Safety and Immunogenicity. Study of 2019-nCoV Vaccine (mRNA-1273) to Prevent SARS-CoV-2 Infection (NCT04283461). Available online: https:/clinicaltrials.gov/ct2/show/ NCT04283461 (accessed on 21 August 2020).

9. Calder, P.C. Immunonutrition. Br. Med. J. 2003, 327, 117-118. [CrossRef] [PubMed]

10. Soares, A.D.N.; Costa, K.A.; Wanner, S.P.; Santos, R.G.C.; Fernandes, S.O.A.; Martins, F.S.; Nicoli, J.R.; Coimbra, C.C.; Cardoso, V.N. Dietary glutamine prevents the loss of intestinal barrier function and attenuates the increase in core body temperature induced by acute heat exposure. Br. J. Nutr. 2014, 112, 1601-1610. [CrossRef] [PubMed]

11. Beale, R.J.; Bryg, D.J.; Bihari, D.J. Immunonutrition in the critically ill: A systematic review of clinical outcome. Crit. Care Med. 1999, 27, 2799-2805. [CrossRef] [PubMed]

12. Heyland, D.K.; Dhaliwal, R.; Suchner, U.; Berger, M.M. Antioxidant nutrients: A systematic review of trace elements and vitamins in the critically ill patient. Intensive Care Med. 2005, 31, 327-337. [CrossRef]

13. Mizock, B.A. Immunonutrition and critical illness: An update. Nutrition 2010, 26, 701-707. [CrossRef] [PubMed]

14. Nelson, J.L.; DeMichele, S.J.; Pacht, E.R.; Wennberg, A.K.; Gadek, J.; Drake, J.; Farmer, P.; Hart, J.; Karlstad, M.; Cruz, E.; et al. Effect of enteral feeding with eicosapentaenoic acid, $\gamma$-linolenic acid, and antioxidants on antioxidant status in patients with acute respiratory distress syndrome. J. Parenter. Enter. Nutr. 2003, 27, 98-104. [CrossRef] [PubMed]

15. Pontes-Arruda, A.; Aragão, A.M.A.; Albuquerque, J.D. Effects of enteral feeding with eicosapentaenoic acid, $\gamma$-linolenic acid, and antioxidants in mechanically ventilated patients with severe sepsis and septic shock. Crit. Care Med. 2006, 34, 2325-2333. [CrossRef] [PubMed]

16. Li, C.; Bo, L.; Liu, W.; Lu, X.; Jin, F. Enteral immunomodulatory diet (omega-3 fatty acid, $\gamma$-linolenic acid and antioxidant supplementation) for acute lung injury and acute respiratory distress syndrome: An updated systematic review and meta-analysis. Nutrients 2015, 7, 5572-5585. [CrossRef]

17. Dushianthan, A.; Cusack, R.; Burgess, V.A.; Grocott, M.P.W.; Calder, P.C. Immunonutrition for acute respiratory distress syndrome (ARDS) in adults. Cochrane Database Syst. Rev. 2019, 1, CD012041. [CrossRef]

18. Caccialanza, R.; Laviano, A.; Lobascio, F.; Montagna, E.; Bruno, R.; Ludovisi, S.; Corsico, A.G.; Di Sabatino, A.; Belliato, M.; Calvi, M.; et al. Early nutritional supplementation in non-critically ill patients hospitalized for the 2019 novel coronavirus disease (COVID-19): Rationale and feasibility of a shared pragmatic protocol. Nutrition 2020, 74, 110835. [CrossRef]

19. Huang, Z.; Liu, Y.; Qi, G.; Brand, D.; Zheng, S. Role of vitamin A in the immune system. J. Clin. Med. 2018, 7, 258. [CrossRef]

20. Retinol|C20H30O-PubChem. Available online: https://pubchem.ncbi.nlm.nih.gov/compound/Retinol (accessed on 17 August 2020). 
21. Lidén, M.; Eriksson, U. Understanding retinol metabolism: Structure and function of retinol dehydrogenases. J. Biol. Chem. 2006, 281, 13001-13004. [CrossRef]

22. Sporn, M.B.; Dunlop, N.M.; Newton, D.L.; Smith, J.M. Prevention of chemical carcinogenesis by vitamin A and its synthetic analogs (retinoids). Fed. Proc. 1976, 35, 1332-1338.

23. Lefebvre, P.; Martin, P.J.; Flajollet, S.; Dedieu, S.; Billaut, X.; Lefebvre, B. Transcriptional Activities of Retinoic Acid Receptors. Vitam. Horm. 2005, 70, 199-264. [CrossRef]

24. Tanumihardjo, S.A. Vitamin A: Biomarkers of nutrition for development. Am. J. Clin. Nutr. 2011, 94, 658S-65S. [CrossRef] [PubMed]

25. Tang, G. Bioconversion of dietary provitamin A carotenoids to vitamin A in humans. Am. J. Clin. Nutr. 2010, 91, 1468S. [CrossRef] [PubMed]

26. Kiser, P.D.; Palczewski, K. Retinoids and retinal diseases. Annu. Rev. Vis. Sci. 2016, 2, 197-234. [CrossRef] [PubMed]

27. Senoo, H.; Yoshikawa, K.; Morii, M.; Miura, M.; Imai, K.; Mezaki, Y. Hepatic stellate cell (vitamin A-storing cell) and its relative-Past, present and future. Cell Biol. Int. 2010, 34, 1247-1272. [CrossRef]

28. Dao, D.Q.; Ngo, T.C.; Thong, N.M.; Nam, P.C. Is vitamin A an antioxidant or a pro-oxidant? J. Phys. Chem. B 2017, 121, 9348-9357. [CrossRef]

29. McGrane, M.M. Vitamin A regulation of gene expression: Molecular mechanism of a prototype gene. J. Nutr. Biochem. 2007, 18, 497-508. [CrossRef]

30. Zhong, M.; Kawaguchi, R.; Kassai, M.; Sun, H. Retina, retinol, retinal and the natural history of vitamin A as a light sensor. Nutrients 2012, 4, 2069-2096. [CrossRef]

31. Herschel Conaway, H.; Henning, P.; Lerner, U.H. Vitamin a metabolism, action, and role in skeletal homeostasis. Endocr. Rev. 2013, 34, 766-797. [CrossRef]

32. Fiedor, J.; Burda, K. Potential role of carotenoids as antioxidants in human health and disease. Nutrients 2014, 6, 466-488. [CrossRef]

33. Jørgensen, M.J.; Hein-Kristensen, L.; Hempel, C.; Ravn, H.; Wiese, L.; Kurtzhals, J.A.L.; Benn, C.S. The effect of vitamin A supplementation and diphtheria-tetanus-pertussis vaccination on parasitaemia in an experimental murine malaria model. Scand. J. Infect. Dis. 2011, 43, 296-303. [CrossRef]

34. Benn, C.S. Combining vitamin A and vaccines: Convenience or conflict? Dan. Med. J. 2012, 59 , B4378. [PubMed]

35. Hollm-Delgado, M.G.; Piel, F.B.; Weiss, D.J.; Howes, R.E.; Stuart, E.A.; Hay, S.I.; Black, R.E. Vitamin A supplements, routine immunization, and the subsequent risk of plasmodium infection among children under 5 years in sub-Saharan Africa. Elife 2015, 4, e03925. [CrossRef] [PubMed]

36. Jayawardena, R.; Sooriyaarachchi, P.; Chourdakis, M.; Jeewandara, C.; Ranasinghe, P. Enhancing immunity in viral infections, with special emphasis on COVID-19: A review. Diabetes Metab. Syndr. Clin. Res. Rev. 2020, 14, 367-382. [CrossRef] [PubMed]

37. Paiva, S.A.R.; Godoy, I.; Vannucchi, H.; Fávaro, R.M.D.; Geraldo, R.R.C.; Campana, A.O. Assessment of vitamin A status in chronic obstructive pulmonary disease patients and healthy smokers. Am. J. Clin. Nutr. 1996, 64, 928-934. [CrossRef]

38. Arora, P.; Kumar, V.; Batra, S. Vitamin A status in children with asthma. Pediatr. Allergy Immunol. 2002, 13, 223-226. [CrossRef]

39. Green, H.N.; Mellanby, E. Vitamin a as an anti-infective agent. Br. Med. J. 1928, 2, 691-696. [CrossRef]

40. Riccioni, G.; Barbara, M.; Bucciarelli, T.; di Ilio, C.; D'Orazio, N. Antioxidant vitamin supplementation in asthma. Ann Clin Lab Sci 2007, 37, 96-101.

41. Villamor, E.; Fawzi, W.W. Effects of vitamin A supplementation on immune responses and correlation with clinical outcomes. Clin. Microbiol. Rev. 2005, 18, 446-464. [CrossRef]

42. Sommer, A.; Katz, J.; Tarwotjo, I. Increased risk of respiratory disease and diarrhea in children with preexisting mild vitamin A deficiency. Am. J. Clin. Nutr. 1984, 40, 1090-1095. [CrossRef]

43. Brown, C.C.; Noelle, R.J. Seeing through the dark: New insights into the immune regulatory functions of vitamin A. Eur. J. Immunol. 2015, 45, 1287-1295. [CrossRef]

44. Aibana, O.; Franke, M.F.; Huang, C.C.; Galea, J.T.; Calderon, R.; Zhang, Z.; Becerra, M.C.; Smith, E.R.; Ronnenberg, A.G.; Contreras, C.; et al. Impact of Vitamin A and carotenoids on the risk of tuberculosis progression. Clin. Infect. Dis. 2017, 65, 900-909. [CrossRef] 
45. Karim, T.; Muhit, M.; Khandaker, G. Interventions to prevent respiratory diseases-Nutrition and the developing world. Paediatr. Respir. Rev. 2017, 22, 31-37. [CrossRef] [PubMed]

46. Schwartz, E.; Zelig, R.; Parker, A.; Johnson, S. Vitamin A supplementation for the prevention of bronchopulmonary dysplasia in preterm infants: An update. Nutr. Clin. Pract. 2017, 32, 346-353. [CrossRef] [PubMed]

47. Araki, S.; Kato, S.; Namba, F.; Ota, E. Vitamin A to prevent bronchopulmonary dysplasia in extremely low birth weight infants: A systematic review and meta-analysis. PLOS ONE 2018, 13, e0207730. [CrossRef] [PubMed]

48. Hustead, V.A.; Gutcher, G.R.; Anderson, S.A.; Zachman, R.D. Relationship of vitamin A (retinol) status to lung disease in the preterm infant. J. Pediatr. 1984, 116, 626-633. [CrossRef]

49. Hashimoto, S.; Hayashi, S.; Yoshida, S.; Kujime, K.; Maruoka, S.; Matsumoto, K.; Gon, Y.; Koura, T.; Horie, T. Retinoic acid differentially regulates interleukin- $1 \beta$ and interleukin-1 receptor antagonist production by human alveolar macrophages. Leuk. Res. 1998, 22, 1057-1061. [CrossRef]

50. Yang, C.; Yang, X.; Du, J.; Wang, H.; Li, H.; Zeng, L.; Gu, W.; Jiang, J. Retinoic acid promotes the endogenous repair of lung stem/progenitor cells in combined with simvastatin after acute lung injury: A stereological analysis. Respir. Res. 2015, 16, 140. [CrossRef]

51. Trottier, C.; Colombo, M.; Mann, K.K.; Miller, W.H.; Ward, B.J. Retinoids inhibit measles virus through a type I IFN-dependent bystander effect. FASEB J. 2009, 23, 3203-3212. [CrossRef]

52. Jee, J.; Hoet, A.E.; Azevedo, M.P.; Vlasova, A.N.; Loerch, S.C.; Pickworth, C.L.; Hanson, J.; Saif, L.J. Effects of dietary vitamin A content on antibody responses of feedlot calves inoculated intramuscularly with an inactivated bovine coronavirus vaccine. Am. J. Vet. Res. 2013, 74, 1353-1362. [CrossRef]

53. West, C.E.; Sijtsma, S.R.; Kouwenhoven, B.; Rombout, J.H.W.M.; Van der Zijpp, A.J. Epithelia-damaging virus infections affect vitamin A status in chickens. J. Nutr. 1992, 122, 333-339. [CrossRef]

54. Litonjua, A.A. Fat-soluble vitamins and atopic disease: What is the evidence? Proc. Nutr. Soc. 2012, 71, 67-74. [CrossRef] [PubMed]

55. U.S. National Library of Medicine. Anti-Inflammatory/Antioxidant Oral Nutrition Supplementation in COVID-19 (ONSCOVID19). Available online: https://clinicaltrials.gov/ct2/show/NCT04323228 (accessed on 21 August 2020).

56. Spinas, E.; Saggini, A.; Kritas, S.K.; Cerulli, G.; Caraffa, A.; Antinolfi, P.; Pantalone, A.; Frydas, A.; Tei, M.; Speziali, A.; et al. Crosstalk Between Vitamin B and Immunity. J. Biol. Regul. Homeost. Agents 2015, 29, 283-288. [PubMed]

57. Neri, M.; Cantatore, S.; Pomara, C.; Riezzo, I.; Bello, S.; Turillazzi, E.; Fineschi, V. Immunohistochemical expression of proinflammatory cytokines IL-1 $\beta$, IL-6, TNF- $\alpha$ and involvement of COX-2, quantitatively confirmed by Western blot analysis, in Wernicke's encephalopathy. Pathol. Res. Pract. 2011, 207, 652-658. [CrossRef] [PubMed]

58. Zhou, E.; Li, Y.; Yao, M.; Wei, Z.; Fu, Y.; Yang, Z. Niacin attenuates the production of pro-inflammatory cytokines in LPS-induced mouse alveolar macrophages by HCA2 dependent mechanisms. Int. Immunopharmacol. 2014, 23, 121-126. [CrossRef]

59. Rodriguez-Melendez, R.; Zempleni, J. Regulation of gene expression by biotin (review). J. Nutr. Biochem. 2003, 14, 680-690. [CrossRef]

60. Marik, P.E.; Khangoora, V.; Rivera, R.; Hooper, M.H.; Catravas, J. Hydrocortisone, vitamin C, and thiamine for the treatment of severe sepsis and septic shock: A retrospective before-after study. Chest 2017, 151, 1229-1238. [CrossRef]

61. Keil, S.D.; Bowen, R.; Marschner, S. Inactivation of Middle East respiratory syndrome coronavirus (MERS-CoV) in plasma products using a riboflavin-based and ultraviolet light-based photochemical treatment. Transfusion 2016, 56, 12. [CrossRef]

62. Kandeel, M.; Al-Nazawi, M. Virtual screening and repurposing of FDA approved drugs against COVID-19 main protease. Life Sci. 2020, 251, 15. [CrossRef]

63. Serseg, T.; Benarous, K.; Yousfi, M. Hispidin and lepidine E: Two natural compounds and folic acid as potential inhibitors of 2019-novel coronavirus Main Protease (2019-nCoVMpro), molecular docking and SAR study. Curr. Comput. Aided. Drug Des. 2020. [CrossRef]

64. European Union. EU Register on Nutrition and Health Claims. Available online: https://ec.europa.eu/food/ safety/labelling_nutrition/claims/register/public (accessed on 21 August 2020). 
65. Calder, P.C.; Carr, A.C.; Gombart, A.F.; Eggersdorfer, M. Optimal nutritional status for a well-functioning immune system is an important factor to protect against viral infections. Nutrients 2020, 12, 1181. [CrossRef]

66. Kishimoto, K.; Kobayashi, R.; Sano, H.; Suzuki, D.; Maruoka, H.; Yasuda, K.; Chida, N.; Yamada, M.; Kobayashi, K. Impact of folate therapy on combined immunodeficiency secondary to hereditary folate malabsorption. Clin. Immunol. 2014, 153, 17-22. [CrossRef]

67. Vogiatzoglou, A.; Refsum, H.; Johnston, C.; Smith, S.M.; Bradley, K.M.; De Jager, C.; Budge, M.M.; Smith, A.D. Vitamin B12 status and rate of brain volume loss in community-dwelling elderly. Neurology 2008, 71, 826-832. [CrossRef]

68. Rocco, A.; Compare, D.; Coccoli, P.; Esposito, C.; Spirito, A.D.; Barbato, A.; Strazzullo, P.; Nardone, G. Vitamin B12 supplementation improves rates of sustained viral response in patients chronically infected with hepatitis C virus. Gut 2013, 62, 766-773. [CrossRef] [PubMed]

69. Manzanares, W.; Hardy, G. Thiamine supplementation in the critically ill. Curr. Opin. Clin. Nutr. Metab. Care 2011, 14, 610-617. [CrossRef] [PubMed]

70. Mallat, J.; Lemyze, M.; Thevenin, D. Do not forget to give thiamine to your septic shock patient! J. Thorac. Dis. 2016, 8, 1062-1066. [CrossRef]

71. Donnino, M.W.; Andersen, L.W.; Chase, M.; Berg, K.M.; Tidswell, M.; Giberson, T.; Wolfe, R.; Moskowitz, A.; Smithline, H.; Ngo, L.; et al. Randomized, double-blind, placebo-controlled trial of thiamine as a metabolic resuscitator in septic shock: A pilot study. Crit. Care Med. 2016, 44, 360-367. [CrossRef] [PubMed]

72. Kim, W.Y.; Jo, E.J.; Eom, J.S.; Mok, J.; Kim, M.H.; Kim, K.U.; Park, H.K.; Lee, M.K.; Lee, K. Combined vitamin $\mathrm{C}$, hydrocortisone, and thiamine therapy for patients with severe pneumonia who were admitted to the intensive care unit: Propensity score-based analysis of a before-after cohort study. J. Crit. Care 2018, 47, 211-218. [CrossRef]

73. Fimognari, F.L.; Loffredo, L.; Di Simone, S.; Sampietro, F.; Pastorelli, R.; Monaldo, M.; Violi, F.; D’Angelo, A. Hyperhomocysteinaemia and poor vitamin B status in chronic obstructive pulmonary disease. Nutr. Metab. Cardiovasc. Dis. 2009, 19, 654-659. [CrossRef]

74. Tsiligianni, I.G.; van der Molen, T. A systematic review of the role of vitamin insufficiencies and supplementation in COPD. Respir. Res. 2010, 11, 171. [CrossRef]

75. Hilgenfeld, R. From SARS to MERS: Crystallographic studies on coronaviral proteases enable antiviral drug design. FEBS J. 2014, 281, 4085-4096. [CrossRef]

76. Jin, Z.; Du, X.; Xu, Y.; Deng, Y.; Liu, M.; Zhao, Y.; Zhang, B.; Li, X.; Zhang, L.; Peng, C.; et al. Structure of Mpro from COVID-19 virus and discovery of its inhibitors. Nature 2020, 582, 289-293. [CrossRef] [PubMed]

77. Padayatty, S.J.; Levine, M. Vitamin C: The known and the unknown and Goldilocks. Oral Dis. 2016, 22, 463-493. [CrossRef] [PubMed]

78. Wang, Y.; Russo, T.A.; Kwon, O.; Chanock, S.; Rumsey, S.C.; Levine, M. Ascorbate recycling in human neutrophils: Induction by bacteria. Proc. Natl. Acad. Sci. USA 1997, 94, 13816-13819. [CrossRef] [PubMed]

79. Nualart, F.J.; Rivas, C.I.; Montecinos, V.P.; Godoy, A.S.; Guaiquil, V.H.; Golde, D.W.; Vera, J.C. Recycling of vitamin C by a bystander effect. J. Biol. Chem. 2003, 278, 10128-10133. [CrossRef]

80. Marik, P.E. Vitamin C: An essential "stress hormone" during sepsis. J. Thorac. Dis. 2020, 2, S84-S88. [CrossRef]

81. Haworth, W.; Hirst, E. Synthesis of ascorbic acid. J. Soc. Chem. Ind. 1933, 52, 645-646. [CrossRef]

82. Pauling, L. Vitamin C and Common Cold. JAMA J. Am. Med. Assoc. 1971, 216, 332. [CrossRef]

83. Pauling, L. Evolution and the need for ascorbic acid. Proc. Natl. Acad. Sci. USA 1970, 67, $1643-1648$. [CrossRef]

84. Thomas, W.R.; Holt, P.G. Vitamin C and immunity: An assessment of the evidence. Clin. Exp. Immunol. 1978, 32, 370-379.

85. Webb, A.L.; Villamor, E. Update: Effects of antioxidant and non-antioxidant vitamin supplementation on immune function. Nutr. Rev. 2007, 65, 181-217. [CrossRef]

86. Hemilä, H. Vitamin C and infectious diseases. In Vitamin C; Springer: Milano, Italy, 1998; pp. $73-85$.

87. Goode, H.F.; Webster, N.R. Free radicals and antioxidants in sepsis. Crit. Care Med. 1993, 21, 1770-1776. [CrossRef] [PubMed]

88. Akaike, T.; Suga, M.; Maeda, H. Free radicals in viral pathogenesis: Molecular mechanisms involving superoxide and NO. Proc. Soc. Exp. Biol. Med. 1998, 217. [CrossRef] [PubMed] 
89. Peterhans, E. Oxidants and antioxidants in viral diseases: Disease mechanisms and metabolic regulation. J. Nutr. 1997, 127, 962S-965S. [CrossRef] [PubMed]

90. Hemilä, H. Do Vitamins C and E Affect Respiratory Infections? Doctoral Thesis, University of Helsinki, Helsinki, Iceland, 2006.

91. Atherton, J.G.; Kratzing, C.C.; Fisher, A. The effect of ascorbic acid on infection of chick-embryo ciliated tracheal organ cultures by coronavirus. Arch. Virol. 1978, 56, 195-199. [CrossRef] [PubMed]

92. Davelaar, F.G.; Van Den Bos, J. Ascorbic acid and infectious bronchitis infections in broilers. Avian Pathol. 1992, 21, 581-589. [CrossRef]

93. Ziegler-Heitbrock, H.W.L.; Sternsdorf, T.; Liese, J.; Belohradsky, B.; Weber, C.; Wedel, A.; Schreck, R.; Bauerle, P.; Strobel, M. Pyrrolidine dithiocarbamate inhibits NF-kB mobilization and TNF production in human monocytes. J. Immunol. 1993, 151, 6986-6993.

94. Lo, S.K.; Janakidevi, K.; Lai, L.; Malik, A.B. Hydrogen peroxide-induced increase in endothelial adhesiveness is dependent on ICAM-1 activation. Am. J. Physiol. Lung Cell. Mol. Physiol. 1993, 264, L406-L412. [CrossRef]

95. DeForge, L.E.; Preston, A.M.; Takeuchi, E.; Kenney, J.; Boxer, L.A.; Remick, D.G. Regulation of interleukin 8 gene expression by oxidant stress. J. Biol. Chem. 1993, 268, 25568-25576.

96. Chen, Y.; Luo, G.; Yuan, J.; Wang, Y.; Yang, X.; Wang, X.; Li, G.; Liu, Z.; Zhong, N. Vitamin C mitigates oxidative stress and tumor necrosis factor-alpha in severe community-acquired pneumonia and LPS-induced macrophages. Mediat. Inflamm. 2014, 2014, 426740. [CrossRef] [PubMed]

97. Auer, B.L.; Auer, D.; Rodgers, A.L. Relative hyperoxaluria, crystalluria and haematuria after megadose ingestion of vitamin C. Eur. J. Clin. Investig. 1998, 28, 695-700. [CrossRef] [PubMed]

98. Taylor, E.N.; Stampfer, M.J.; Curhan, G.C. Dietary factors and the risk of incident kidney stones in men: New insights after 14 years of follow-up. J. Am. Soc. Nephrol. 2004, 15, 3225-3232. [CrossRef] [PubMed]

99. Hemilä, H.; Chalker, E. Vitamin C for preventing and treating the common cold. Cochrane Database Syst. Rev. 2013. [CrossRef]

100. Hemilä, H. Vitamin C and infections. Nutrients 2017, 9, 339. [CrossRef] [PubMed]

101. Peters, E.M.; Goetzsche, J.M.; Grobbelaar, B.; Noakes, T.D. Vitamin C supplementation reduces the incidence of postrace symptoms of upper-respiratory-tract infection in ultramarathon runners. Am. J. Clin. Nutr. 1993, 57, 170-174. [CrossRef] [PubMed]

102. Peters, T.D. Vitamin $C$ as effective as combinations of anti-oxidant nutrients in reducing symptoms of upper respiratory tract infection in ultramarathon runners. South Afr. J. Sport. Med. 1996, 3, $23-27$.

103. Moolla, M.E. The Effect of Supplemental Anti-Oxidants on the Incidence and Severity of Upper Respiratory Infections in Ultra Marathon Runners. Master's Thesis, University of Capetown, Cape Town, South Africa, 1996.

104. Sabiston, B.H.; Radomski, M.W. Health Problems and Vitamin C in Canadian Northern Military Operations; Defence and Civil Institute of Environmental Medicine Report No. 74-R-M2; University of Helsinki: Helsinki, Finland, 1974.

105. Bosmann, M.; Ward, P.A. The inflammatory response in sepsis. Trends Immunol. 2013, 34, 129-136. [CrossRef]

106. Grommes, J.; Soehnlein, O. Contribution of neutrophils to acute lung injury. Mol. Med. 2011, 17, $293-307$. [CrossRef]

107. Brinkmann, V.; Reichard, U.; Goosmann, C.; Fauler, B.; Uhlemann, Y.; Weiss, D.S.; Weinrauch, Y.; Zychlinsky, A. Neutrophil extracellular traps kill bacteria. Science 2004, 303, 1532-1535. [CrossRef]

108. Mohammed, B.M.; Fisher, B.J.; Kraskauskas, D.; Farkas, D.; Brophy, D.F.; Fowler, A.A.; Natarajan, R. Vitamin C: A novel regulator of neutrophil extracellular trap formation. Nutrients 2013, 5, 3131-3151. [CrossRef]

109. Erol, N.; Saglam, L.; Saglam, Y.S.; Erol, H.S.; Altun, S.; Aktas, M.S.; Halici, M.B. The protection potential of antioxidant vitamins against acute respiratory distress syndrome: A rat trial. Inflammation 2019, 42, 1585-1594. [CrossRef]

110. Fisher, B.J.; Kraskauskas, D.; Martin, E.J.; Farkas, D.; Wegelin, J.A.; Brophy, D.; Ward, K.R.; Voelkel, N.F.; Fowler, A.A.; Natarajan, R. Mechanisms of attenuation of abdominal sepsis induced acute lung injury by ascorbic acid. Am. J. Physiol. Lung Cell. Mol. Physiol. 2012, 303, L20-L32. [CrossRef] [PubMed]

111. Levine, M.; Conry-Cantilena, C.; Wang, Y.; Welch, R.W.; Washko, P.W.; Dhariwal, K.R.; Park, J.B.; Lazarev, A.; Graumlich, J.F.; King, J.; et al. Vitamin C pharmacokinetics in healthy volunteers: Evidence for a recommended dietary allowance. Proc. Natl. Acad. Sci. USA 1996, 93, 3704-3709. [CrossRef] [PubMed] 
112. Maulén, N.P.; Henríquez, E.A.; Kempe, S.; Cárcamo, J.G.; Schmid-Kotsas, A.; Bachem, M.; Grünert, A.; Bustamante, M.E.; Nualart, F.; Vera, J.C. Up-regulation and polarized expression of the sodium-ascorbic acid transporter SVCT1 in post-confluent differentiated CaCo-2 cells. J. Biol. Chem. 2003, 278, 9035-9041. [CrossRef] [PubMed]

113. Kashiouris, M.G.; L'heureux, M.; Cable, C.A.; Fisher, B.J.; Leichtle, S.W.; Fowler, A.A. The emerging role of vitamin $C$ as a treatment for sepsis. Nutrients 2020, 12, 292. [CrossRef]

114. Carr, A.C.; Rosengrave, P.C.; Bayer, S.; Chambers, S.; Mehrtens, J.; Shaw, G.M. Hypovitaminosis C and vitamin $C$ deficiency in critically ill patients despite recommended enteral and parenteral intakes. Crit. Care 2017, 21, 300. [CrossRef]

115. Fowler, A.A.; Truwit, J.D.; Hite, R.D.; Morris, P.E.; Dewilde, C.; Priday, A.; Fisher, B.; Thacker, L.R.; Natarajan, R.; Brophy, D.F.; et al. Effect of vitamin C infusion on organ failure and biomarkers of inflammation and vascular injury in patients with sepsis and severe acute respiratory failure: The CITRIS-ALI randomized clinical trial. JAMA J. Am. Med Assoc. 2019, 322, 1261-1270. [CrossRef]

116. Marik, P.E.; Payen, D. CITRIS-ALI: How statistics were used to obfuscate the true findings. Anaesth. Crit. Care Pain Med. 2019, 38, 575-577. [CrossRef]

117. Hemilä, H.; Chalker, E. Vitamin C can shorten the length of stay in the ICU: A meta-analysis. Nutrients 2019, 11, 708. [CrossRef]

118. Zhang, M.; Jativa, D.F. Vitamin C supplementation in the critically ill: A systematic review and meta-analysis. SAGE Open Med. 2018, 6, 2050312118807615. [CrossRef]

119. Marik, P.E. Patterns of death in patients with sepsis and the use of hydrocortisone, ascorbic acid, and thiamine to prevent these deaths. Surg. Infect. (Larchmt) 2018, 19, 8. [CrossRef]

120. Rice, T.W.; Wheeler, A.P.; Thompson, B.T.; DeBoisblanc, B.P.; Steingrub, J.; Rock, P. Enteral omega-3 fatty acid, $\gamma$-linolenic acid, and antioxidant supplementation in acute lung injury. JAMA J. Am. Med. Assoc. 2011, 306, 1574-1581. [CrossRef] [PubMed]

121. Chen, L.; Hu, C.; Hood, M.; Zhang, X.; Zhang, L.; Kan, J.; Du, J. A novel combination of vitamin C, curcumin and glycyrrhizic acid potentially regulates immune and inflammatory response associated with coronavirus infections: A perspective from system biology analysis. Nutrients 2020, 12, 1193. [CrossRef] [PubMed]

122. Hager, D.N.; Hooper, M.H.; Bernard, G.R.; Busse, L.W.; Ely, E.W.; Fowler, A.A.; Gaieski, D.F.; Hall, A.; Hinson, J.S.; Jackson, J.C.; et al. The Vitamin C, Thiamine and Steroids in Sepsis (VICTAS) Protocol: A prospective, multi-center, double-blind, adaptive sample size, randomized, placebo-controlled, clinical trial. Trials 2019, 20, 197. [CrossRef] [PubMed]

123. Senses, H. Vitamin C Effective Against COVID-19: Expert; Anadolu Agency: Ankara, Turkey, 2020.

124. Australian Government. No Evidence to Support Intravenous High-Dose Vitamin C in the Management of COVID-19; Therapeutic Goods Administration: Symonston, Australia, 2020.

125. M2 PressWIRE. Single vitamins see $166 \%$ growth as consumers look to boost immunity during COVID-19 lockdown. Eastern Daylight Time, 28 April 2020.

126. U.S. National Library of Medicine. Use of Ascorbic Acid in Patients with COVID 19. Available online: https://clinicaltrials.gov/ct2/show/NCT04323514 (accessed on 21 August 2020).

127. U.S. National Library of Medicine. Vitamin C Infusion for the Treatment of Severe 2019-nCoV Infected Pneumonia (NCT04264533). Available online: https://clinicaltrials.gov/ct2/show/NCT04264533 (accessed on 21 August 2020).

128. Mahmoudi, M.; Rezaei, N. Nutrition and Immunity; Springer: Berlin/Heidelberg, Germany, 2019.

129. Lips, P.; Van Schoor, N.M. The effect of vitamin D on bone and osteoporosis. Best Pract. Res. Clin. Endocrinol. Metab. 2011, 25, 585-591. [CrossRef] [PubMed]

130. Bikle, D.D. Chemistry \& biology review vitamin D metabolism, mechanism of action, and clinical applications. Chem. Biol. 2014, 21, 319-329. [CrossRef]

131. Lee, P.; Eisman, J.A.; Center, J.R. Vitamin D Deficiency in Critically Ill Patients. N. Engl. J. Med. 2011, 364, 1882. [CrossRef]

132. Quraishi, S.A.; Litonjua, A.A.; Moromizato, T.; Gibbons, F.K.; Camargo, C.A.; Giovannucci, E.; Christopher, K.B. Association between prehospital vitamin D status and hospitalacquired bloodstream infections. Am. J. Clin. Nutr. 2013, 98, 952-959. [CrossRef] 
133. Braun, A.B.; Litonjua, A.A.; Moromizato, T.; Gibbons, F.K.; Giovannucci, E.; Christopher, K.B. Association of low serum 25-hydroxyvitamin D levels and acute kidney injury in the critically ill. Crit. Care Med. 2012, 40, 3170-3179. [CrossRef]

134. Thickett, D.R.; Moromizato, T.; Litonjua, A.A.; Amrein, K.; Quraishi, S.A.; Lee-Sarwar, K.A.; Mogensen, K.M.; Purtle, S.W.; Gibbons, F.K.; Camargo, C.A.; et al. Association between prehospital vitamin d status and incident acute respiratory failure in critically ill patients: A retrospective cohort study. BMJ Open Respir. Res. 2015, 2, 1-8. [CrossRef]

135. Moromizato, T.; Litonjua, A.A.; Braun, A.B.; Gibbons, F.K.; Giovannucci, E.; Christopher, K.B. Association of low serum 25-hydroxyvitamin D levels and sepsis in the critically ill. Crit. Care Med. 2014, 42, 97-107. [CrossRef]

136. Braun, A.B.; Gibbons, F.K.; Litonjua, A.A.; Giovannucci, E.; Christopher, K.B. Low serum 25-hydroxyvitamin $\mathrm{D}$ at critical care initiation is associated with increased mortality. Crit. Care Med. 2012, 40, 63-72. [CrossRef] [PubMed]

137. McLaughlin, L.; Clarke, L.; Khalilidehkordi, E.; Butzkueven, H.; Taylor, B.; Broadley, S.A. Vitamin D for the treatment of multiple sclerosis: A meta-analysis. J. Neurol. 2018, 265, 2893-2905. [CrossRef] [PubMed]

138. Law, A.D.; Dutta, U.; Kochhar, R.; Vaishnavi, C.; Kumar, S.; Noor, T.; Bhadada, S.; Singh, K. Vitamin D deficiency in adult patients with ulcerative colitis: Prevalence and relationship with disease severity, extent, and duration. Indian J. Gastroenterol. 2019, 38, 6-14. [CrossRef] [PubMed]

139. White, J.H. Vitamin D deficiency and the pathogenesis of Crohn's disease. J. Steroid Biochem. Mol. Biol. 2018, 175, 23-28. [CrossRef]

140. Pfeffer, P.E.; Hawrylowicz, C.M. Vitamin D in asthma: Mechanisms of action and considerations for clinical trials. Chest 2018, 153, 1229-1239. [CrossRef]

141. Holick, M.F. Medical progress: Vitamin D deficiency. N. Engl. J. Med. 2007, 357, 266-281. [CrossRef]

142. Gröber, U.; Kisters, K. Influence of drugs on vitamin D and calcium metabolism. Dermatoendocrinol. 2012, 4, 158-166. [CrossRef]

143. Medicine, I. Dietary Reference Intakes for Calcium and Vitamin D; National Academies Press: Washington, DC, USA, 2011.

144. Scientific Advisory Committee on Nutrition (SACN). Vitamin D and Health 2016 ii. 2016. Available online: https://www.gov.uk/government/publications/sacn-vitamin-d-and-health-report (accessed on 21 August 2020).

145. Beard, J.A.; Bearden, A.; Striker, R. Vitamin D and the anti-viral state. J. Clin. Virol. 2011, 50, $194-200$. [CrossRef]

146. Spector, S.A. Vitamin D and HIV: Letting the sun shine in. Top. Antivir. Med. 2011, 19, 6.

147. Campbell, G.R.; Spector, S.A. Autophagy induction by vitamin D inhibits both Mycobacterium tuberculosis and human immunodeficiency virus type 1. Autophagy 2012, 8, 1523-1525. [CrossRef]

148. Grant, W.B.; Lahore, H.; McDonnell, S.L.; Baggerly, C.A.; French, C.B.; Aliano, J.L.; Bhattoa, H.P. Evidence that vitamin D supplementation could reduce risk of influenza and covid-19 infections and deaths. Nutrients 2020, 12, 988. [CrossRef] [PubMed]

149. Rondanelli, M.; Miccono, A.; Lamburghini, S.; Avanzato, I.; Riva, A.; Allegrini, P.; Faliva, M.A.; Peroni, G.; Nichetti, M.; Perna, S. Self-care for common colds: The pivotal role of vitamin D, vitamin C, zinc, and echinacea in three main immune interactive clusters (physical barriers, innate and adaptive immunity) involved during an episode of common colds-Practical advice on dosages and on the time to take these nutrients/botanicals in order to prevent or treat common colds. Evid. Based Complement. Altern. Med. 2018, 2018, 5813095. [CrossRef]

150. Schwalfenberg, G.K. A review of the critical role of vitamin D in the functioning of the immune system and the clinical implications of vitamin D deficiency. Mol. Nutr. Food Res. 2011, 55, 96-108. [CrossRef] [PubMed]

151. Kast, J.I.; McFarlane, A.J.; Głobińska, A.; Sokolowska, M.; Wawrzyniak, P.; Sanak, M.; Schwarze, J.; Akdis, C.A.; Wanke, K. Respiratory syncytial virus infection influences tight junction integrity. Clin. Exp. Immunol. 2017, 190, 351-359. [CrossRef]

152. McCartney, D.M.; Byrne, D.G. Optimisation of vitamin D status for enhanced immuno-protection against COVID-19. Ir. Med. J. 2020, 113, 58. 
153. Vankadari, N.; Wilce, J.A. Emerging WuHan (COVID-19) coronavirus: Glycan shield and structure prediction of spike glycoprotein and its interaction with human CD26. Emerg. Microbes Infect. 2020, 9, 601-604. [CrossRef]

154. Skariyachan, S.; Challapilli, S.B.; Packirisamy, S.; Kumargowda, S.T.; Sridhar, V.S. Recent aspects on the pathogenesis mechanism, animal models and novel therapeutic interventions for middle east respiratory syndrome coronavirus infections. Front. Microbiol. 2019, 10, 569. [CrossRef]

155. Liu, P.T.; Stenger, S.; Li, H.; Wenzel, L.; Tan, B.H.; Krutzik, S.R.; Ochoa, M.T.; Schauber, J.; Wu, K.; Meinken, C.; et al. Toll-like receptor triggering of a vitamin D-mediated human antimicrobial response. Science 2006, 311, 1770-1773. [CrossRef]

156. Adams, J.S.; Ren, S.; Liu, P.T.; Chun, R.F.; Lagishetty, V.; Gombart, A.F.; Borregaard, N.; Modlin, R.L.; Hewison, M. Vitamin d-directed rheostatic regulation of monocyte antibacterial responses. J. Immunol. 2009, 182, 4289-4295. [CrossRef]

157. Martínez-Moreno, J.; Hernandez, J.C.; Urcuqui-Inchima, S. Effect of high doses of vitamin D supplementation on dengue virus replication, toll-like receptor expression, and cytokine profiles on dendritic cells. Mol. Cell. Biochem. 2020, 464, 169-180. [CrossRef]

158. Dancer, R.C.A.; Parekh, D.; Lax, S.; D’Souza, V.; Zheng, S.; Bassford, C.R.; Park, D.; Bartis, D.G.; Mahida, R.; Turner, A.M.; et al. Vitamin D deficiency contributes directly to the acute respiratory distress syndrome (ARDS). Thorax 2015, 70, 617-624. [CrossRef] [PubMed]

159. Barnett, N.; Zhao, Z.; Koyama, T.; Janz, D.R.; Wang, C.Y.; May, A.K.; Bernard, G.R.; Ware, L.B. Vitamin D deficiency and risk of acute lung injury in severe sepsis and severe trauma: A case-control study. Ann. Intensive Care 2014, 4, 5. [CrossRef] [PubMed]

160. Braun, A.; Chang, D.; Mahadevappa, K.; Gibbons, F.K.; Liu, Y.; Giovannucci, E.; Christopher, K.B. Association of low serum 25-hydroxyvitamin D levels and mortality in the critically ill. Crit. Care Med. 2011, 39, 671-677. [CrossRef] [PubMed]

161. Cantorna, M.T.; Snyder, L.; Lin, Y.D.; Yang, L. Vitamin D and 1,25(OH)2D regulation of T cells. Nutrients 2015, 7, 3011-3021. [CrossRef]

162. Jeffery, L.E.; Burke, F.; Mura, M.; Zheng, Y.; Qureshi, O.S.; Hewison, M.; Walker, L.S.K.; Lammas, D.A.; Raza, K.; Sansom, D.M. 1,25-Dihydroxyvitamin D 3 and IL-2 combine to inhibit T cell production of inflammatory cytokines and promote development of regulatory T cells expressing CTLA-4 and foxp3. J. Immunol. 2009, 183, 5458-5467. [CrossRef]

163. Lin, S.; Wu, H.; Wang, C.; Xiao, Z.; Xu, F. Regulatory T cells and acute lung injury: Cytokines, uncontrolled inflammation, and therapeutic implications. Front. Immunol. 2018, 9, 1545. [CrossRef]

164. Lei, G.S.; Zhang, C.; Cheng, B.H.; Lee, C.H. Mechanisms of action of vitamin D as supplemental therapy for Pneumocystis pneumonia. Antimicrob. Agents Chemother. 2017, 61. [CrossRef]

165. Xu, J.; Yang, J.; Chen, J.; Luo, Q.; Zhang, Q.; Zhang, H. Vitamin D alleviates lipopolysaccharide-induced acute lung injury via regulation of the renin-angiotensin system. Mol. Med. Rep. 2017, 16, 7432-7438. [CrossRef]

166. Hansdottir, S.; Monick, M.M.; Hinde, S.L.; Lovan, N.; Look, D.C.; Hunninghake, G.W. Respiratory epithelial cells convert inactive vitamin D to its active form: Potential effects on host defense. J. Immunol. 2008, 181, 7090-7099. [CrossRef]

167. Imai, Y.; Kuba, K.; Rao, S.; Huan, Y.; Guo, F.; Guan, B.; Yang, P.; Sarao, R.; Wada, T.; Leong-Poi, H.; et al. Angiotensin-converting enzyme 2 protects from severe acute lung failure. Nature 2005, 436, 112-116. [CrossRef]

168. Martineau, A.R.; Jolliffe, D.A.; Hooper, R.L.; Greenberg, L.; Aloia, J.F.; Bergman, P.; Dubnov-Raz, G.; Esposito, S.; Ganmaa, D.; Ginde, A.A.; et al. Vitamin D supplementation to prevent acute respiratory tract infections: Systematic review and meta-analysis of individual participant data. BMJ 2017, 356, i6583. [CrossRef] [PubMed]

169. Imai, Y.; Kuba, K.; Penninger, J.M. The discovery of angiotensin-converting enzyme 2 and its role in acute lung injury in mice. Exp. Physiol. 2008, 93, 543-548. [CrossRef] [PubMed]

170. Jia, H. Pulmonary Angiotensin-Converting Enzyme 2 (ACE2) and inflammatory lung disease. Shock 2016, 46, 239-248. [CrossRef] [PubMed]

171. Cao, Y.; Li, L.; Feng, Z.; Wan, S.; Huang, P.; Sun, X.; Wen, F.; Huang, X.; Ning, G.; Wang, W. Comparative genetic analysis of the novel coronavirus (2019-nCoV/SARS-CoV-2) receptor ACE2 in different populations. Cell Discov. 2020, 6, 1-4. [CrossRef] 
172. La Vignera, S.; Cannarella, R.; Condorelli, R.A.; Torre, F.; Aversa, A.; Calogero, A.E. Sex-Specific SARS-CoV-2 mortality: Among hormone-modulated ACE2 expression, risk of venous thromboembolism and hypovitaminosis, D. Int. J. Mol. Sci. 2020, 21, 2948. [CrossRef] [PubMed]

173. Fitzgerald, M.; Shyamsundar, M.; McNamee, J.; Thickett, D.; O'Kane, C.; McAuley, D. S67 Vitamin D deficiency drives pulmonary inflammation in a human model of the acute respiratory distress syndrome induced by inhaled lipopolysaccharide in healthy volunteers. Thorax 2015, 70, A40-A41. [CrossRef]

174. Panarese, A.; Shahini, E. Letter: Covid-19, and vitamin D. Aliment. Pharmacol. Ther. 2020, 51, $993-995$. [CrossRef]

175. Jakovac, H. COVID-19 and vitamin D-Is there a link and an opportunity for intervention? Am. J. Physiol. Endocrinol. Metab. 2020, 318, E589. [CrossRef]

176. Knibbs, J. Vitamin D deficiency: How lacking in the essential vitamin increases risk from Covid-19. Express Online 2020, 8, 570.

177. Prema, S. Health expert explains why getting just $10 \mathrm{~min}$ of sunshine every day could make you less vulnerable to COVID-19-With low vitamin D levels increasing the risk of lung infections. Daily Mail, 28 April 2020.

178. Bieber, N. Coronavirus: Vitamin D could "treat" Covid-19 as scientists launch investigation. Daily Star, 20 April 2020.

179. Pinkstone, J. People with low levels of Vitamin D may be more likely to catch coronavirus and die from COVID-19 infection, study suggests. Daily. Mail, 1 May 2020.

180. Pinkstone, J. More evidence vitamin D can help against coronavirus: Study finds patients with a severe deficiency are TWICE as likely to die from COVID-19. Daily Mail Online, 8 May 2020.

181. Ridley, M. It is time to take seriously the link between Vitamin D deficiency and more serious Covid-19 symptoms. Telegr, 3 May 2020.

182. Chapman, A. Coronavirus warning: Low levels of this vitamin is linked to worse treatment outcomes. Express Online, 30 April 2020.

183. NPA Pharmacy Services Team. Updated Advice on Vitamin D Intake during COVID-19 Pandemic; National Pharmacy Association: St Albans, UK, 2020.

184. Knibbs, J. Vitamin D and coronavirus: How the sunshine vitamin could help with COVID-19 infection. Express Online, 2 May 2020.

185. Sunderland, C. Trinity College study says Vitamin D could help fight against Covid-19 infections. Irish Exam, 3 April 2020.

186. Chapman, A. Best supplements for the immune system: The vitamin proven to prevent infection. Express Online, 4 April 2020.

187. Allister Vitamin D could help in fight against Covid-19. Irish Medical Times, 6 April 2020.

188. Ring, E. Irish studies find Vitamin D can build Covid-19 resistance. Irish Exam, 3 April 2020.

189. Atherton, M. Coronavirus-the cheap supplements that could 'fight off" COVID-19 infection. Express Online, 24 April 2020.

190. Rhodes, J.; Subramanian, S.; Laird, E.; Kenny, R.A. COVID-19, vitamin D and latitude. University of Liverpool News, 21 April 2020.

191. Ilie, P.C.; Stefanescu, S.; Smith, L. The role of vitamin D in the prevention of coronavirus disease 2019 infection and mortality. Aging Clin. Exp. Res. 2020, 1. [CrossRef]

192. Rhodes, J.M.; Subramanian, S.; Laird, E.; Anne Kenny, R. Editorial: Low population mortality from COVID-19 in countries south of latitude 35 degrees North—supports vitamin D as a factor determining severity. Aliment. Pharmacol. Ther. 2020, 51, 1434-1437. [CrossRef] [PubMed]

193. COvid-19 and Vitamin D Supplementation: A Multicenter Randomized Controlled Trial of High Dose Versus Standard Dose Vitamin D3 in High-Risk COVID-19 Patients (CoVitTrial)—Full Text View_ClinicalTrials.gov. Available online: https:/clinicaltrials.gov/ct2/show/NCT04344041 (accessed on 4 May 2020).

194. Vitamin D on Prevention and Treatment of COVID-19-Full Text View-ClinicalTrials.gov. Available online: https://clinicaltrials.gov/ct2/show/NCT04334005 (accessed on 4 May 2020).

195. Traber, M.G. Vitamin E Regulatory Mechanisms. Annu. Rev. Nutr. 2007, 27, 347-362. [CrossRef] [PubMed]

196. Ikeda, S.; Toyoshima, K.; Yamashita, K. Dietary sesame seeds elevate $\alpha$ - and $\gamma$-tocotrienol concentrations in skin and adipose tissue of rats fed the tocotrienol-rich fraction extracted from palm oil. J. Nutr. 2001, 131, 2892-2897. [CrossRef] [PubMed] 
197. Peh, H.Y.; Tan, W.S.D.; Liao, W.; Wong, W.S.F. Vitamin E therapy beyond cancer: Tocopherol versus tocotrienol. Pharmacol. Ther. 2016, 162, 152-169. [CrossRef] [PubMed]

198. Serbinova, E.; Kagan, V.; Han, D.; Packer, L. Free radical recycling and intramembrane mobility in the antioxidant properties of alpha-tocopherol and alpha-tocotrienol. Free Radic. Biol. Med. 1991, 10, $263-275$. [CrossRef]

199. Suzuki, Y.J.; Tsuchiya, M.; Wassall, S.R.; Choo, Y.M.; Govil, G.; Kagan, V.E.; Packer, L. Structural and dynamic membrane properties of $\alpha$-tocopherol and $\alpha$-tocotrienol: Implication to the molecular mechanism of their antioxidant potency. Biochemistry 1993, 32, 10692-10699. [CrossRef]

200. Bieri, J.G.; Corash, L.; Van Hubbard, S. Medical Uses of Vitamin, E. N. Engl. J. Med. 1983, 308, $1063-1071$. [CrossRef]

201. Tappel, A.L.; Dillard, C.J. In vivo lipid peroxidation: Measurement via exhaled pentane and protection by vitamin E. Fed. Proc. 1981, 40, 174-178.

202. Hafeman, D.G.; Hoekstra, W.G. Lipid Peroxidation in Vivo during Vitamin E and Selenium Deficiency in the Rat as Monitored by Ethane Evolution. J. Nutr. 1977, 107, 666-672. [CrossRef]

203. Richard, C.; Lemonnier, F.; Thibault, M.; Couturier, M.; Auzepy, P. Vitamin E deficiency and lipoperoxidation during adult respiratory distress syndrome. Crit. Care Med. 1990, 18, 4-9. [CrossRef]

204. Lee, G.Y.; Han, S.N. The role of vitamin E in immunity. Nutrients 2018, 10, 1614. [CrossRef] [PubMed]

205. Traber, M.G.; Atkinson, J. Vitamin E, antioxidant and nothing more. Free Radic. Biol. Med. 2007, 43, 4-15. [CrossRef] [PubMed]

206. Meydani, S.N.; Leka, L.S.; Fine, B.C.; Dallal, G.E.; Keusch, G.T.; Singh, M.F.; Hamer, D.H. Vitamin E and respiratory tract infections in elderly nursing home residents: A randomized controlled trial. J. Am. Med. Assoc. 2004, 292, 828-836. [CrossRef] [PubMed]

207. Thompson, B.T.; Chambers, R.C.; Liu, K.D. Acute respiratory distress syndrome. N. Engl. J. Med. 2017, 377, 562-572. [CrossRef]

208. Wong, C.; Flynn, J.; Demling, R.H. Role of oxygen radicals in endotoxin-induced lung injury. Arch. Surg. 1984, 119, 77-82. [CrossRef]

209. Takeda, K.; Shimada, Y.; Amano, M.; Sakai, T.; Okada, T.; Yoshiya, I. Plasma lipid peroxides and alpha-tocopherol in critically ill patients. Crit. Care Med. 1984, 12, 957-959. [CrossRef]

210. Bertrand, Y.; Pincemail, J.; Hanique, G.; Denis, B.; Leenaerts, L.; Vankeerberghen, L.; Deby, C. Differences in tocopherol-lipid ratios in ARDS and non-ARDS patients. Intensive Care Med. 1989, 15, 87-93. [CrossRef]

211. Hybertson, B.M.; Kitlowski, R.P.; Jepson, E.K.; Repine, J.E. Supercritical fluid-aerosolized vitamin E pretreatment decreases leak in isolated oxidant-perfused rat lungs. J. Appl. Physiol. 1998, 84, 263-268. [CrossRef]

212. Hybertson, B.M.; Leff, J.A.; Beehler, C.J.; Barry, P.C.; Repine, J.E. Effect of vitamin E deficiency and supercritical fluid aerosolized vitamin E supplementation on interleukin-1-induced oxidative lung injury in rats. Free Radic. Biol. Med. 1995, 18, 537-542. [CrossRef]

213. Wolf, H.R.D.; Seeger, H.W. Experimental and clinical results in shock lung treatment with vitamin E. Ann. N. Y. Acad. Sci. 1982, 93, 392-410. [CrossRef]

214. Meydani, S.N. Vitamin E supplementation and in vivo immune response in healthy elderly subjects. JAMA 1997, 277, 1380-1386. [CrossRef] [PubMed]

215. Wu, D.; Meydani, S. Age-associated changes in immune function: Impact of vitamin E intervention and the underlying mechanisms. Endocrine Metab. Immune Disord. Targets 2014, 14, 283-289. [CrossRef] [PubMed]

216. De la Fuente, M.; Hernanz, A.; Guayerbas, N.; Victor, V.M.; Arnalich, F. Vitamin E ingestion improves several immune functions in elderly men and women. Free Radic. Res. 2008, 42, 272-280. [CrossRef] [PubMed]

217. Tian, S.; Hu, W.; Niu, L.; Liu, H.; Xu, H.; Xiao, S.Y. Pulmonary pathology of early-phase 2019 novel coronavirus (COVID-19) pneumonia in two patients with lung cancer. J. Thorac. Oncol. 2020, 15, 700-704. [CrossRef]

218. Xu, Z.; Shi, L.; Wang, Y.; Zhang, J.; Huang, L.; Zhang, C.; Liu, S.; Zhao, P.; Liu, H.; Zhu, L.; et al. Pathological findings of COVID-19 associated with acute respiratory distress syndrome. Lancet Respir. Med. 2020, 8, 420-422. [CrossRef]

219. Beck, M.A.; Handy, J.; Levander, O.A. Host nutritional status: The neglected virulence factor. Trends Microbiol. 2004, 12, 417-423. [CrossRef]

220. Front Line COVID-19 Critical Care Working Group Treatment Protocol. Available online: https: //covid19criticalcare.com/math-hospital-treatment/ (accessed on 21 August 2020). 
221. Butt, J.; Okoli, G. BAME Covid-19 deaths demand a broader inquiry. The Guardian, 20 April 2020.

222. Atherton, M. Coronavirus: Why you should be adding a supplement to your diet after government advice. Express Online, 23 April 2020.

223. Welsh Government. Vitamin D Advice for Everyone: Coronavirus. Available online: https://gov.wales/ vitamin-d-advice-everyone-coronavirus (accessed on 8 May 2020).

224. Public Health Agency PHA Recommends Daily Vitamin D Supplement During Lockdown. Available online: https://www.publichealth.hscni.net/news/pha-recommends-daily-vitamin-d-supplement-duringlockdown (accessed on 15 May 2020).

225. Scottish Government Vitamin D: Advice for All Age Groups. Available online: https://www.gov.scot/ publications/vitamin-d-advice-for-all-age-groups/ (accessed on 15 May 2020).

226. NHS England Vitamin, D. Available online: https://www.nhs.uk/conditions/vitamins-and-minerals/vitamind/ (accessed on 15 May 2020).

227. Hastie, C.E.; Mackay, D.F.; Ho, F.; Celis-Morales, C.A.; Katikireddi, S.V.; Niedzwiedz, C.L.; Jani, B.D.; Welsh, P.; Mair, F.S.; Gray, S.R.; et al. Vitamin D concentrations and COVID-19 infection in UK Biobank. Diabetes Metab. Syndr. Clin. Res. Rev. 2020, 14, 561-565. [CrossRef]

(C) 2020 by the authors. Licensee MDPI, Basel, Switzerland. This article is an open access article distributed under the terms and conditions of the Creative Commons Attribution (CC BY) license (http://creativecommons.org/licenses/by/4.0/). 